\title{
Computer-aided design, synthesis, and biological evaluation of [4.3.0] bicyclic prolyl oligopeptidase and fibroblast activation protein- $\alpha$ dual inhibitors
}

Jessica Plescia, Damien Hédou, Maud Eva Pousse, Anne Labarre, Caroline Dufresne, Anthony Mittermaier, and Nicolas Moitessier*

Department of Chemistry, McGill University, 801 Sherbrooke St. W., Montréal, Québec H3A 0B8, Canada.

*E-mail: nicolas.moitessier@mcgill.ca

\begin{abstract}
We have previously described several different chemical series of bicyclic prolyl oligopeptidase (POP) inhibitors as probes for neurodegenerative diseases that demonstrated nanomolar activity in vitro and submicromolar activity in cellulo. The more recent implication of POP in cancer, together with homologous fibroblast activation protein $\alpha$ (FAP), implicated in tumor growth, led us to consider developing POP/FAP dual inhibitors as a promising strategy for the development of cancer therapeutics. We report herein docking-guided design of a new bicyclic scaffold and synthesis of both covalent and non-covalent bicyclic inhibitors. Biological evaluation of first-of-their-kind [4.3.0] bicyclic compounds confirmed that reactive groups, or covalent warheads, are required for inhibitor activity. This work ultimately led to a dual inhibitor equipotent to the only anti-POP/FAP drug that ever-reached clinical trials.
\end{abstract}

\section{Introduction.}

Prolyl oligopeptidase (POP, also referred to as PREP) and fibroblast activation protein- $\square$ (FAP, also referred to as seprase) are homologous serine proteases whose function consists of cleaving short peptides at the C-terminal end of proline residues. POP was discovered in the mid-70's, and its high concentration in the central nervous system (CNS) immediately drew attention; ${ }^{1-3}$ early studies associated POP protease activity to neuropeptides and peptide hormones. Inhibition of this protease activity was first investigated with the reversible covalent inhibitor 1 over thirty years ago (Figure 1). However, after significant targeted research and unsuccessful clinical trials, this 
progress reached a plateau (Figure 1). In more recent years, a second boost in the development of POP inhibitors has occurred, and their potential in Alzheimer's disease (AD) and Parkinson's disease (PD) has been under further investigation. ${ }^{1-4}$ More specifically, about 10 years ago, Lambeir and co-workers first linked POP to $\alpha$-synuclein (aSyn) aggregation, a hallmark of PD, ${ }^{5}$ and Myöhänen and co-workers revealed the colocalization of POP with aSyn, amyloid beta (A $\beta$ ), and the tau protein in brain samples from patients with PD or AD. ${ }^{6}$ The link between POP and aSyn aggregation was further supported by extensive studies by Myöhänen and co-workers who first showed that aggregation is induced by POP-aSyn protein-protein interaction and is unrelated to the protease activity of POP. ${ }^{7,8}$ The same group also demonstrated the effect of KYP-2047, a POP inhibitor (Figure 2), on aSyn aggregate clearance ${ }^{9,10}$ and the restoration of motor behavior in mouse models, ${ }^{11}$ while Lee and co-workers identified POP inhibitors and confirmed their effect on aSyn expression. ${ }^{12}$ In 2011 then in 2015, work by Lambeir then Savolainen et al. suggested that POP interacts with aSyn serving as nucleation point, hence inducing aggregation. ${ }^{13,14}$ More unexpectedly, they observed that KYP-2047 modulates the shape of POP and reduces its ability to interact with aSyn and reduce its aggregation. ${ }^{14}$ Using a combination of NMR and small angle Xray scattering, Giralt and co-workers revealed that POP inhibitors significantly impact this protein dynamics. ${ }^{15}$ In agreement with Savolainen et al.'s observations, ${ }^{14}$ they propose that while POP exists as an equilibrium of open and close conformations necessary to induce aSyn aggregation, POP bound to an inhibitor is more rigid adopting primarily the closed conformation which does not induce aggregation.

In addition to these recent advances in neurodegenerative research linking POP to AD and PD, this enzyme's proteolytic activity was also recently found to contribute to the release of acetylSDKP, a potent tetrapeptide that stimulates angiogenesis. ${ }^{16}$ It has since been reported that POP inhibition blocks the growth of human gastric cancer cells ${ }^{17}$ and the proliferation of breast cancer cells. ${ }^{18}$ We have also demonstrated that our own inhibitors (series based on $\mathbf{2}$ and $\mathbf{3}$, Figure 1) can block POP protease activity in various cancer cell lines. ${ }^{19,20}$ The endopeptidase activity of POP is shared with FAP, the latter of which is suggested to be a key modulator of the tumor microenvironment (TME) $)^{21-23}$ and is thus a promising target for novel anticancer therapeutics. ${ }^{24}$ Discovered over 10 years after POP, FAP is overexpressed in most human epithelial-derived cancers $^{25}$ and has also been suggested to promote tumor growth. ${ }^{21,26}$ In fact, its inhibition significantly affects stromal growth in vivo. ${ }^{22}$ Most importantly, FAP is not detectable in normal 
tissues ${ }^{27}$ making it an extremely valuable target for therapeutic intervention against refractory tumors, and inhibitor development has in fact already started (Figure 2). ${ }^{28-30}$<smiles>O=CC1CCCN1C(=O)[C@@H]1CCCN1C(=O)OCc1ccccc1</smiles>

1, Z-Pro-Prolinal (ZPP)

POP: $K_{\mathrm{i}}=0.29 \mathrm{nM}$

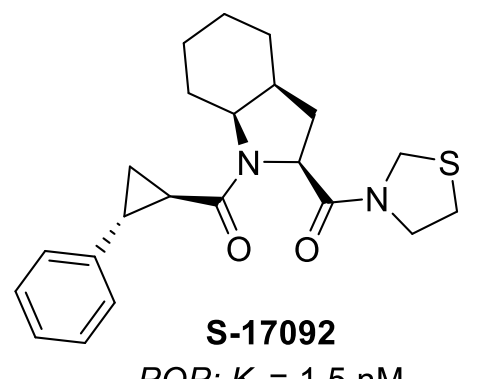

$P O P: K_{\mathrm{i}}=1.5 \mathrm{nM}$

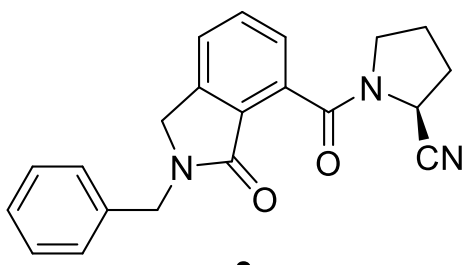

3

POP: $\mathrm{IC}_{50}=45 \mathrm{nM}$

FAP: $I C_{50}>10,000 \mathrm{nM}$

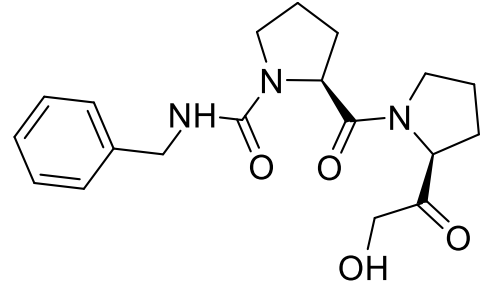

JTP-4819

POP: $\mathrm{IC}_{50}=0.83 \mathrm{nM}$
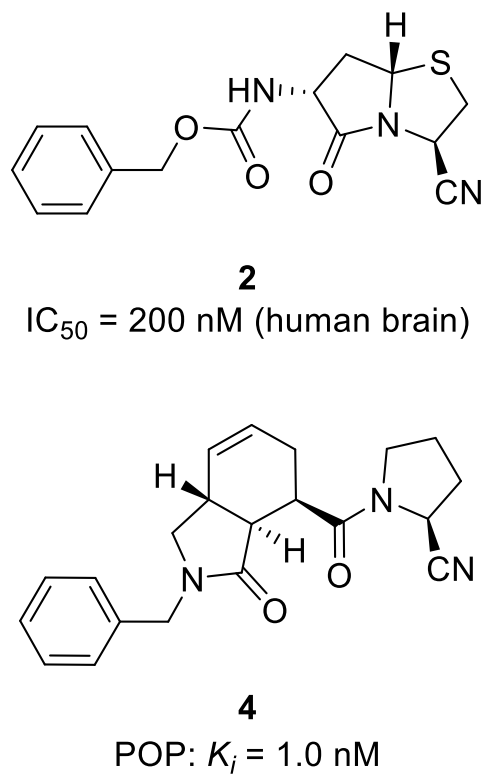

Figure 1. Selected POP and FAP inhibitors

In recent medicinal chemistry endeavors, selective inhibition of one enzyme over the other has been pursued. As illustrated in Figure 2 selectivity is very sensitive to minor structural changes. For example, while compound $\mathbf{5}$ is highly FAP selective, the analogue $\mathbf{6}$ is highly POP selective. This D-Ala-induced selectivity for FAP has been further observed recently. ${ }^{31}$ Nevertheless, Christiansen et al. suggested that targeting both FAP and POP blocks stromal invasion and angiogenesis, respectively, and may alter cancer growth. ${ }^{32}$ They designed a pseudopeptide dual inhibitor which was found to block tumor growth in mice. These findings suggest that dual inhibition is a promising strategy, though this large, non-drug-like molecule was unsuitable for further consideration. ${ }^{33}$ Consequently, although an overview of the literature suggests that 
selectivity may be easier to achieve than dual inhibition, the latter may be an ideal strategy for designing and developing anti-cancer therapeutics.

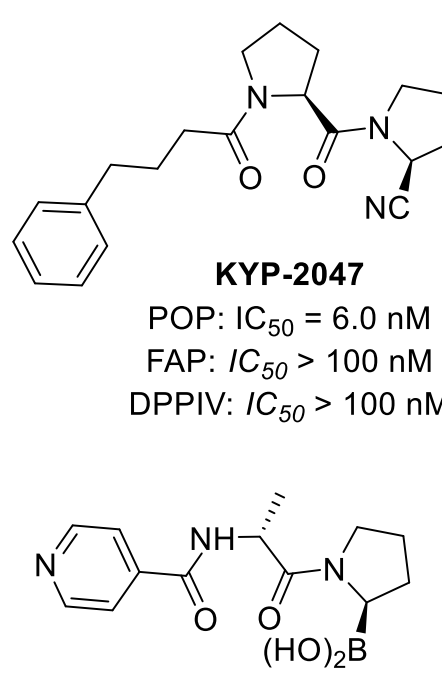

5, Poplawski et al.,2013:

POP: $\mathrm{IC}_{50}>10,000$

FAP: $\mathrm{IC}_{50}=36 \mathrm{nM}$<smiles></smiles>

7, Tran et al., 2007

FAP: $K_{\mathrm{i}}=14 \mathrm{nM}$

POP: $K_{\mathrm{i}}=2.7 \mathrm{nM}$

DPP-IV: $K_{\mathrm{i}}=9080 \mathrm{nM}$<smiles>N#C[C@H]1CC(F)(F)CN1C(=O)CNC(=O)c1cccc2ccccc12</smiles>

9, Ryabtsova et al., 2012

FAP: $K_{\mathrm{i}}=110 \mathrm{nM}$

POP: $K_{\mathrm{i}}=4,800 \mathrm{nM}$

DPP-IV: $K_{\mathrm{i}}>100,000 \mathrm{nM}$<smiles>[B]C1CCCN1C(=O)C(CN)C(C)C</smiles>

Talabostat

FAP: $\mathrm{IC}_{50}=66 \mathrm{nM}$

POP: $\mathrm{IC}_{50}=980 \mathrm{nM}$

DPP-IV: $I_{50}=22 \mathrm{nM}$

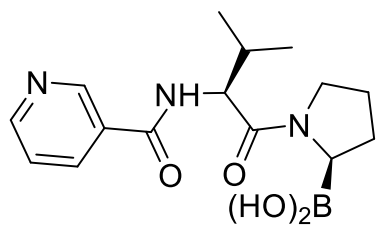

6, Poplawski et al., 2013:

POP: $\mathrm{IC}_{50}=1.3 \mathrm{nM}$

FAP: $I_{50}>100,000 \mathrm{nM}$

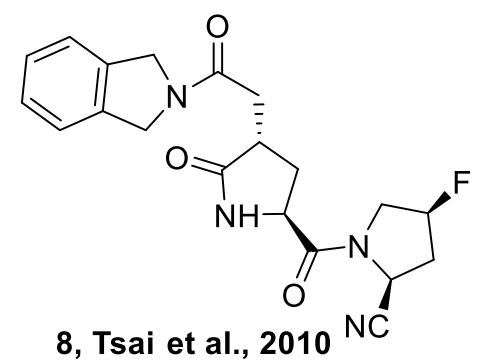

FAP: $I_{50}=20 \mathrm{nM}$

DPP-IV: $I C_{50}>50,000 \mathrm{nM}$<smiles>N#C[C@@H]1CCCN1C(=O)CNC12CC3CC(CC(O)(C3)C1)C2</smiles>

\section{Vildagliptin}

FAP: IC $_{50}=52,000 \mathrm{nM}$

POP: $I C_{50}>100,000 \mathrm{nM}$

DPP-IV: $I_{50}=120 \mathrm{nM}$

Figure 2. Selected known POP and FAP inhibitors and their selectivity profiles ${ }^{28,30,34,35}$

In 2009, our own group reported a series of [3.3.0] bicyclic POP inhibitors based on compound 2 which were found to be cell-permeant and potent in the sub-micromolar range. This series of nitrile-containing compounds were designed to act as covalent inhibitors targeting the catalytic 
serine in the POP active site. ${ }^{19}$ Interestingly, a few years later, KYP-2047 was co-crystallized with POP, demonstrating the covalent nature of the binding of nitrile derivatives in the active site of POP. ${ }^{36}$ However, the series of inhibitors based on compound 2 was halted after metabolism studies revealed it to be metabolized into complex mixtures via oxidation of the sulfur. ${ }^{37} \mathrm{~A}$ few years later, compound $\mathbf{3}$ was discovered via virtual screening and docking-guided optimization, This inhibitor exhibited a POP inhibitory activity five times more potent than that of our first hit $\mathbf{2}$ and was active in low-micromolar concentrations on human glioblastoma and endothelial cancer cells. ${ }^{20}$ In addition, we found that the introduction of the [4.3.0] bicyclic molecular scaffold improved the metabolic stability of our inhibitors. ${ }^{20}$

Five years ago, we also reported the structure-based design and synthesis of a novel class of POP inhibitors based on a hexahydroisoindole scaffold, such as 4 (Figure 1). A docking study guided the selection of structures (both in terms of stereo- and regiochemistry) for synthesis. Following the synthesis of the best virtual candidates, in vitro assays revealed that one member of this chemical series, compound $\mathbf{4}$, was more active than any of our previous inhibitors, exhibiting a $K_{i}$ of $1.0 \mathrm{nM}$. Additional assays also showed that the scaffold of this potent inhibitor, in contrast to the series based on compound $\mathbf{2}$, is highly metabolically stable. ${ }^{38}$ However, upon in vitro testing of $\mathbf{3}$ and $\mathbf{4}$ against recombinant FAP, they were completely inactive. Analysis of docking poses revealed a lack of stabilizing interactions with the two glutamic acid residues in the active site of FAP (Glu203 and Glu204).

With this information in hand, we became interested in the design of dual POP/FAP inhibitors. We report herein our successful efforts in the development of dual inhibitors based on an improved bicyclic core.

\section{Results and discussion}

Computer-aided design. With our first three series of POP inhibitors illustrated by compounds 2, 3 and 4, we have demonstrated the accuracy of our docking program FITTED ${ }^{39-41}$ in predicting binding modes of POP covalent inhibitors. When $\mathbf{2}$ and stereoisomers of $\mathbf{2}$ (adhering to the [3.3.0] bicyclic system) were evaluated, we found that the stereochemistry corresponding to that of Damino acids was optimal (hydrogen atom highlighted in blue in Figure 3, compound 2). The resultant stereochemistry upon cyclization (hydrogen atom highlighted in green in Figure 3 ) at the 
ring junction fortunately imposed a shape that fit best in the binding site. In this previous report, ${ }^{19}$ computational studies also indicated that this [3.3.0] bicyclic system was less optimal for binding to POP, and that a [4.3.0]-ring system with a specific stereochemistry should exhibit better affinity (Figure 3, compound 2a). ${ }^{22}$ Unfortunately, our synthetic efforts were vain, as the epimer at the ring junction (hydrogen atom highlighted in green in Figure 3, compound 2a) was the only isomer observed experimentally but was not predicted to bind optimally in the active site of POP.
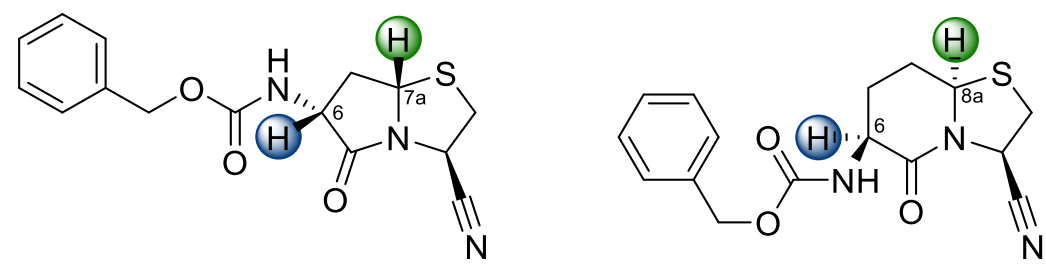

Figure 3. POP inhibitors designed by our group in the past, including required stereochemistry for optimal inhibitor stabilization in the active site of POP (highlighted with blue and green hydrogens).

Further computational predictions indicated that the affinity for POP could be improved by increasing the size of the western ring and inverting two stereocenters, both the carbon at the cyclic fusion $\left(\mathrm{C}_{7 \mathrm{a}}\right.$ in $\mathbf{2}, \mathrm{C}_{8 \mathrm{a}}$ in $\left.\mathbf{2 a}\right)$ and the carbon alpha to the cyclic amide $\left(\mathrm{C}_{6}\right)$. To do so, we decided to prepare a first series of analogues built around a [4.3.0]-ring system similar to that of 2a but which could be accessible synthetically. After several rounds of virtual modifications and docking predictions, inhibitor structure 10a was discovered. As can be seen in Figure 4, the predicted binding mode of nitrile 10a is highly favored, featuring the same key interactions as potent aldehyde 1. 


\section{A}

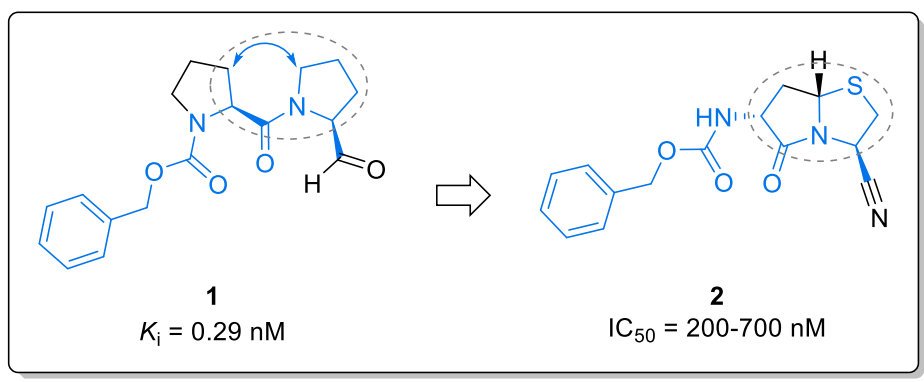

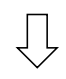

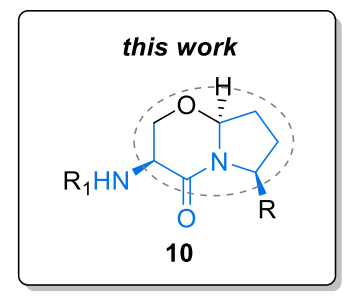

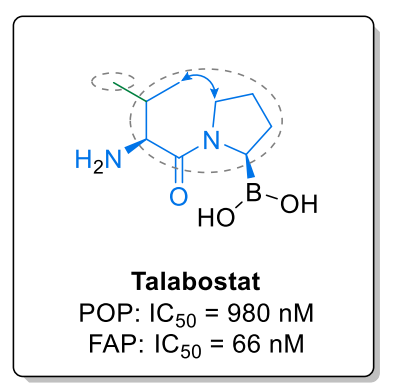

$\sqrt{ }$

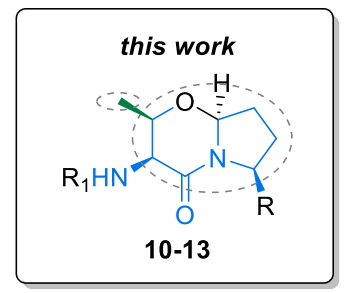

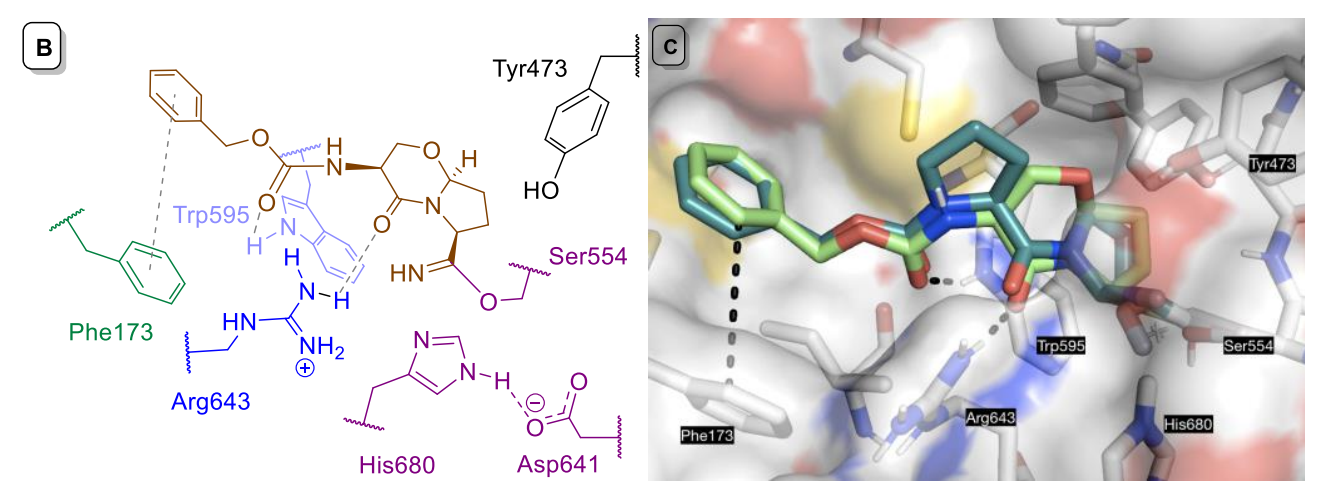

Figure 4. In silico design of a new series of bicycles. (A) Previously designed POP inhibitors and newly designed series of potential dual inhibitors. (B) Schematic representation of the predicted binding pose of 10a (brown) in the POP active site, catalytic triad in purple, key residues in blue/green; (C) predicted binding mode of 10a (green), overlaid with the predicted binding mode of 1 (teal) (docked to POP using FITTED, pdb code: 2xdw)

This prediction encouraged us to pursue the synthesis of compound 10a and other analogues. Our previous inhibitor 2 and this newly-designed scaffold resemble previously-reported potent inhibitor 1 (Figure 4). The bicyclic scaffolds 2 and 10 were introduced by virtually rigidifying 1 and introducing heterocyclic alkanes to both optimize the docking pose and ensure synthetic feasibility. The valine-based side chain of Talabostat (Figure 2), a POP-FAP inhibitor that reached Phase III clinical trials, ${ }^{42}$ inspired the introduction of methyl groups into 10a and incorporation of 
the boronic acid warhead, leading to $\mathbf{1 2 c}$ and $\mathbf{1 3 b}$. The complete list of new analogues selected for synthesis is provided in Table 1.

Table 1. Newly designed bicyclic analogues.

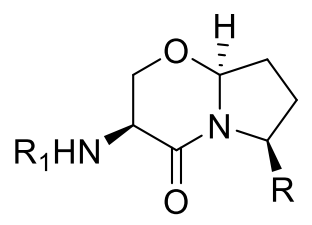

10

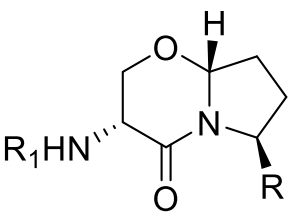

11<smiles></smiles>

12<smiles>[R1]N[C@H]1C(=O)N2C([R])CC[C@H]2O[C@@H]1C</smiles>

13

\begin{tabular}{|c|c|c|c|}
\hline Entry & Compound \# & $\mathrm{R}$ & $\mathrm{R}_{1}$ \\
\hline 1 & $10 a$ & $\mathrm{CN}$ & $\mathrm{Cbz}$ \\
\hline 2 & $10 \mathrm{~b}$ & $\mathrm{H}$ & $\mathrm{Cbz}$ \\
\hline 3 & $10 \mathrm{c}$ & Bpnd & $\mathrm{Cbz}$ \\
\hline 4 & 10d & Bpnd & Ac \\
\hline 5 & $10 \mathrm{e}$ & Bpnd & Boc \\
\hline 6 & $10 f$ & $\mathrm{~B}(\mathrm{OH})_{2}$ & $\mathrm{H}$ \\
\hline 7 & $11 \mathrm{a}$ & Bpnd & Boc \\
\hline 8 & 11b & $\mathrm{B}(\mathrm{OH})_{2}$ & $\mathrm{H}$ \\
\hline 9 & $12 \mathbf{a}$ & Bpnd & $\mathrm{Cbz}$ \\
\hline 10 & $12 \mathrm{~b}$ & Bpnd & Boc \\
\hline 11 & $12 \mathrm{c}$ & $\mathrm{B}(\mathrm{OH})_{2}$ & $\mathrm{H}$ \\
\hline 12 & $13 a$ & Bpnd & Boc \\
\hline 13 & $13 b$ & $\mathrm{~B}(\mathrm{OH})_{2}$ & $\mathrm{H}$ \\
\hline
\end{tabular}


Many POP inhibitors feature nitriles, activated nitriles (i.e., with proximal fluorine atoms), or boronic acids, the latter two of which are more electrophilic and lead to more potent FAP inhibition. Our current version of our docking program FITTED does not consider either the reactivity of the catalytic residue nor the reactive warhead. Nevertheless, a computational study from our group on the reactivity of the catalytic serine residues in both POP and FAP suggests that the catalytic serine in POP is more nucleophilic than that in FAP and that, as a result, nitrile derivatives are unlikely to act as potent covalent inhibitors of FAP, while boronic acids are promising alternatives. ${ }^{43,44}$ As a result, in our quest to develop dual POP/FAP inhibitors, the boronic ester or acid derivatives were also considered.

Boronic acids have been widely used in medicinal chemistry, notably as warheads of reversible covalent inhibitors of proteases, ${ }^{45,46}$ including two approved drugs (Bortezomib and Ixazomib for the treatment of relapsed multiple myeloma and mantle cell lymphoma) ${ }^{47}$ In addition, boronic acids are remarkably stable despite their high reactivity and consistently display very low toxicology profiles. ${ }^{48,49}$ Consequently, we designed our bicyclic boropeptides to be structurally close to Talabostat (Figure 4), a multi-target inhibitor, which entered Phase III clinical trials for the treatment of advanced non-small cell lung cancer. ${ }^{42}$ However, Talabostat displayed a loss in efficacy in vivo believed to be a result of a reversible intramolecular cyclization into an inactive cyclic adduct. ${ }^{50}$ The constrained scaffold of our designed boronic acids 10f, 11b, 12c, and 13b would circumvent this cyclization.

Furthermore, in both POP and FAP, the boronic acid motif may act as a transition state analogue, forming both hydrogen bonds (with His680 and Tyr473 and with His734 and Tyr571, respectively) and covalent bonds with the catalytic triad (Ser554 and Ser624, respectively) in a tetrahedral configuration, as opposed to the trigonal planar configuration conferred by nitrilecontaining inhibitors (Figure 4). Nonetheless, the design of FAP/POP dual inhibitors remains challenging due to the difference in polarity between the active sites. While three hydrophobic or hydrogen bond donor residues contribute the necessary interactions for high inhibition of POP (aromatic interactions with Phe173 and hydrogen bonding with Trp595 and Arg643), high inhibition of FAP relies on interaction with hydrogen bond acceptors Glu203 and Glu204 in the hydrophilic pocket (Figure 5). 

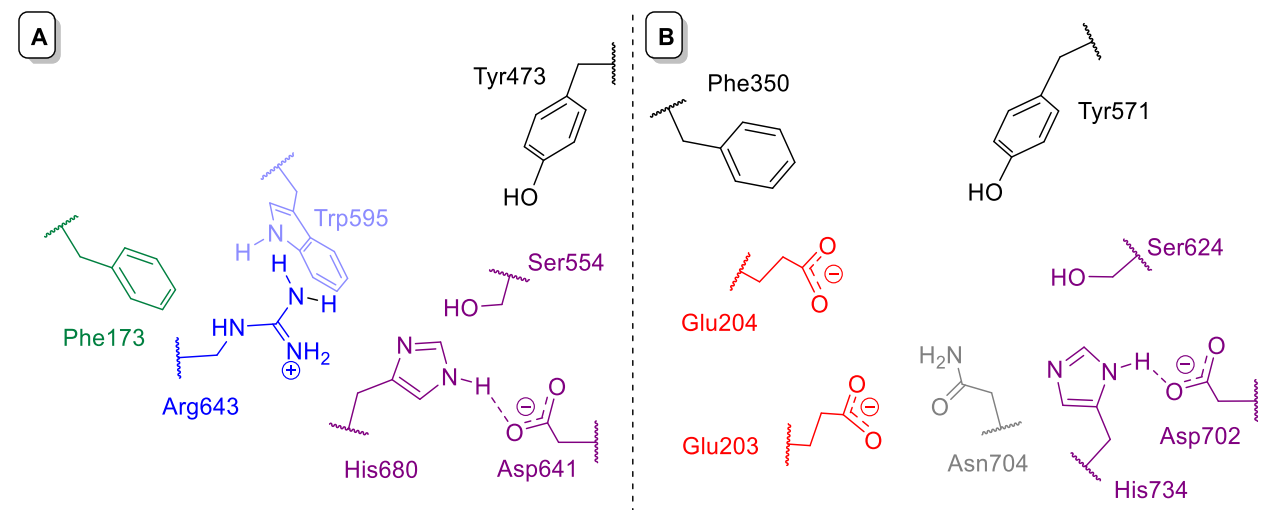

Figure 5. Schematic representation of the active sites of POP and FAP. Catalytic triads shown in purple. (A) POP: positively-charged pocket shown in blue, aromatic interaction residue shown in green; (B) FAP: negatively-charged pocket shown in red
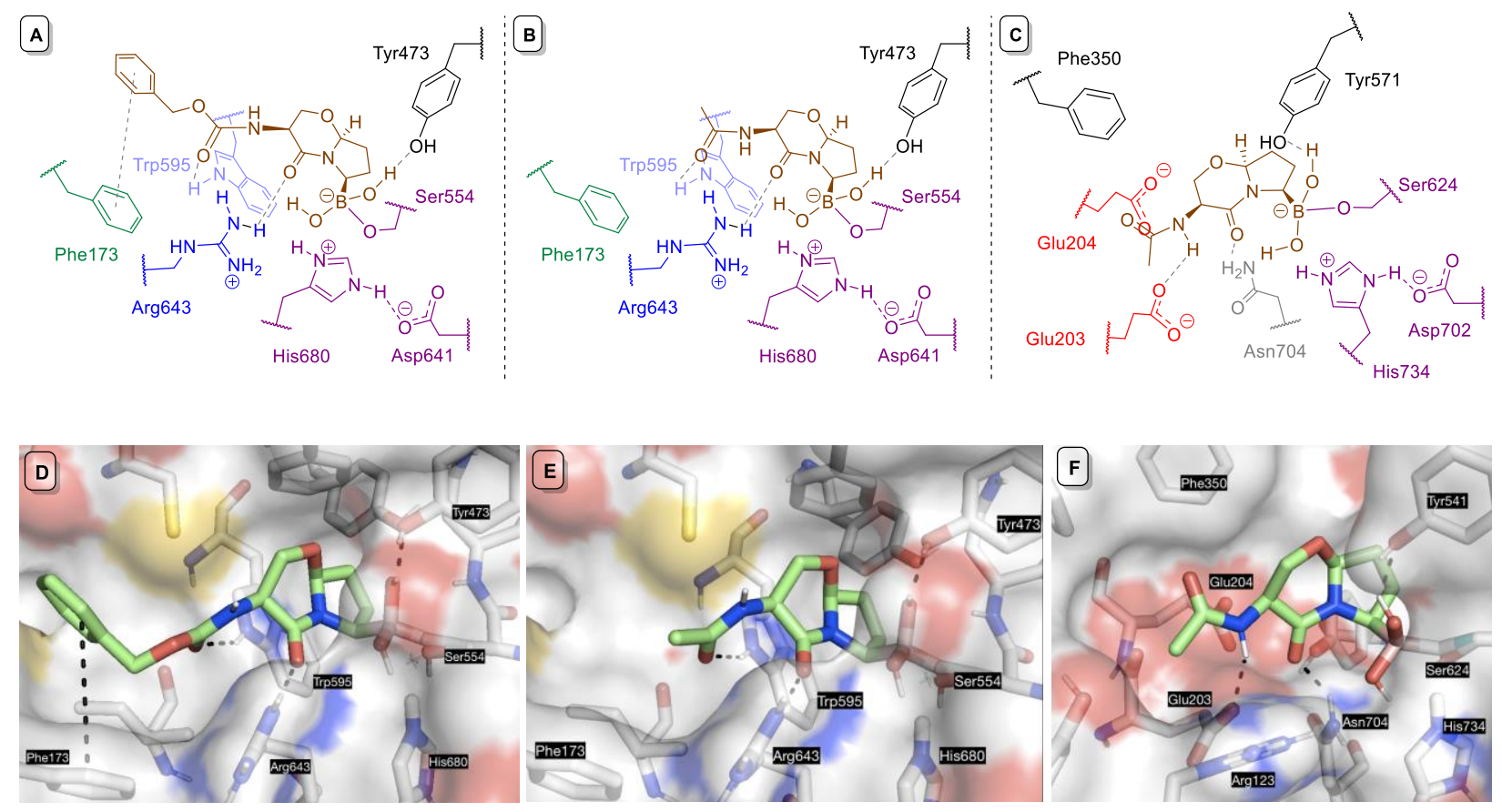

Figure 6. Predicted poses of compounds $10 \mathrm{c}$ and $\mathbf{1 0 d}$ in the active sites of POP and FAP.(A) schematic representation of the predicted binding mode of 10c (brown) in POP; (B) schematic representation of the predicted binding mode of 10d (brown) in POP; (C) Schematic representation of the predicted binding mode of 10d (brown) in FAP; (D) predicted binding mode of 10c (green) (pdb code: $2 \mathrm{xdw}$ ); (E) predicted binding mode of 10d (green) in POP; (F) predicted binding mode of 10d (green) in FAP. All compounds were docked using FITTED. For schematic representations: 
catalytic triads are shown in purple, key residues are shown in blue/green (POP) and red (FAP). n.b. the hydrolyzed boronic esters (boronic acids) were docked.

Upon docking to POP, the $N$-Cbz boronic ester derivative 10c was observed to fit very well into the active site of POP (Figure 6A), while docking to FAP gave unfavorable proposed binding modes, as the carboxybenzyl group is too large to fit into the active site (not shown). This compound is therefore expected to be selective for POP. After virtual optimization of the amide side chain, the acetyl group turned out to be an excellent compromise for the design of potent dual inhibitors, as key interactions were conserved. The $N$-acetyl group may act as a hydrogen bond donor in FAP (with Glu203 or 204) and as a hydrogen bond acceptor in POP (with Trp595). The docking-predicted binding mode of the $N$-acetyl analog in both POP and FAP is shown in Figure 6. Furthermore, in order to evaluate the impact of the covalent warhead, the non-covalent analog 10b was also prepared.

\section{Synthesis}

Non-covalent series. The synthesis of this new [4.3.0] series started with the simplest of the analogues, the non-covalent inhibitor. Compound 10b was synthesized in 3 overall steps starting with coupling $N$-Cbz-L-Ser to readily available 5-amino-1-pentene, followed by a telescoped acidcatalyzed oxidative cyclization (Scheme 1). Through the course of condition optimization, it was determined that performing the ozonolysis in presence of triphenylphosphine significantly increased the isolated yields and diastereoselectivity. In addition, a convenient procedure using resin-supported triphenylphosphine was developed in order to facilitate the purifications.

Scheme 1. Synthesis of the non-covalent series ${ }^{a}$

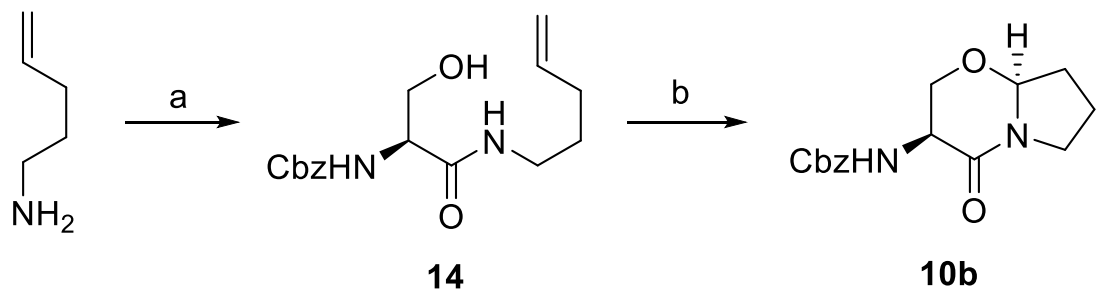

a) N-Cbz-L-Ser, EDC $\cdot \mathrm{HCl}, \mathrm{HOBt} \cdot \mathrm{H}_{2} \mathrm{O}, \mathrm{Et}_{3} \mathrm{~N}, \mathrm{DCM}, 0^{\circ} \mathrm{C} \rightarrow \mathrm{rt}, 18 \mathrm{~h}, 78 \%$; b) 1) $\mathrm{O}_{3}$, Sudan III, $\mathrm{PPh}_{3}, \mathrm{DCM}$, $\left.-78{ }^{\circ} \mathrm{C} \rightarrow \mathrm{rt}, 20 \mathrm{~h} ; 2\right) \mathrm{TFA}, \mathrm{DCM}, \mathrm{rt}, 2 \mathrm{~h}, 40 \%$ over 2 steps. 
Carbonitrile series. The synthesis of $\mathbf{1 0 a}$ was unfortunately much more complex than that of the non-covalent analogue 10b. Many attempts to obtain stereopure $\alpha$-amino nitrile were unsuccessful; syntheses were long and yielded racemic mixtures. The synthesis was therefore redesigned, adapting chemistry from the Ellman group to obtain enantiopure sulfinylimine $15,{ }^{51}$ followed by a modified Strecker reaction adapted from Mabic et. al. ${ }^{52}$ to obtain sulfinamide 16, which was deprotected in $\mathrm{HCl}$ to obtain stereopure $\alpha$-amino carbonitrile 17 (Scheme 2). This amine was subsequently coupled to $N$-Cbz-L-Ser with good yield to give peptide 18. Subsequent acidcatalyzed oxidative cyclization gave desired diastereopure inhibitor 10a.

Scheme 2. Synthesis of the carbonitrile series ${ }^{\mathrm{a}}$

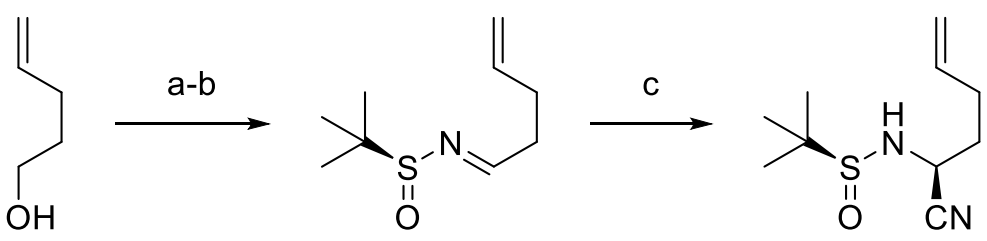

15

16<smiles>C=CCC[C@H](C)NC(=O)[C@H](CO)NC(=O)C(C)C</smiles>

18

17

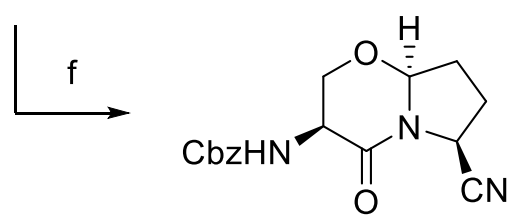

$10 a$

a) $(\mathrm{COCl})_{2}, \mathrm{DMSO}, \mathrm{Et}_{3} \mathrm{~N},-78^{\circ} \mathrm{C} \rightarrow \mathrm{rt}, 2 \mathrm{~h}$; b) $(S)$-(-)-tert-butyl-sulfinylamide, $\mathrm{CuSO}_{4}, \mathrm{DCM}, \mathrm{rt}, 18 \mathrm{~h}, 62 \%$ over two steps; c) TMSCN, Gd(OTf) $3,0^{\circ} \mathrm{C} \rightarrow \mathrm{rt}, 48 \mathrm{~h}, 60 \%$, d.r. 97:3; d) $\mathrm{HCl}, \mathrm{Et}_{2} \mathrm{O}, 0^{\circ} \mathrm{C}, 1 \mathrm{~h}$, quant.; e) $N$ Cbz-L-Ser, EDC $\bullet \mathrm{HCl}, \mathrm{HOBt} \cdot \mathrm{H}_{2} \mathrm{O}, \mathrm{Et}_{3} \mathrm{~N}, \mathrm{DCM}, 0^{\circ} \mathrm{C} \rightarrow \mathrm{rt}, 18 \mathrm{~h}, 80 \%$; f) $\mathrm{O}_{3}$, Sudan III, $\mathrm{PPh}_{3}, \mathrm{DCM},-78$ ${ }^{\circ} \mathrm{C} \rightarrow \mathrm{rt}, 20 \mathrm{~h}$; 2) TFA, DCM, rt, 2h, 33\% over 2 steps

Boronic ester series. This series was prepared following a similar diastereoselective synthetic strategy, starting with the synthesis of sulfinylimine intermediate $\mathbf{1 5 \mathbf { a } ^ { 5 1 }}$ ( 
Scheme 3). The imine reacted under modified Ellman copper-catalyzed hydroboration conditions to afford the desired $\alpha$-sulfinamidoboronic ester 19 with a good isolated yield and high diastereoselectivity.$^{53} \mathrm{~A}$ subsequent transesterification of the pinacol protecting group with the chiral (+)-pinanediol, followed by the deprotection of the sulfinamide group gave the highly diastereopure $\alpha$-aminoboronic ester hydrochloride salt 20. Peptide coupling of 20 provided the boropeptides, which were subjected to oxidative cleavage and dehydrative cyclization to obtain the corresponding bicycles as the sole diastereomers, confirmed by 1D nOe experiments (Figure 7).

To obtain the acetyl-protected bicyclic boronic ester, the $\mathrm{N}$-Cbz-protected bicycle derivative 10c was subjected to hydrogenation conditions, giving the free amine intermediate, which was subsequently reacted with $\mathrm{AcCl}$ to give the $\mathrm{N}$-acetyl derivative 10d ( 
Scheme 3). Unfortunately, attempts to purify the free amine boronic ester intermediate for biological testing were unsuccessful, as purification conditions affected the boronic ester group. This led us to another route, coupling amine $\mathbf{2 0}$ to $N$-Boc-protected amino acids, followed by acidcatalyzed oxidative cyclization and subsequent simultaneous removal of the Boc and (+)pinanediol protecting groups, obtaining the free amine boronic acid bicycles with no necessary purification. Our group has previously demonstrated that boronic esters are quickly hydrolyzed to their respective boronic acids in the basic buffer used in the in vitro assays. ${ }^{43,44}$ The difference in covalent warhead within this series should therefore have negligible effect on the biological activity of these compounds. The complete synthesis of the boronic esters and acids is detailed in 
Scheme 3. 
Scheme 3. Synthesis of boronic ester series ${ }^{\mathrm{a}}$

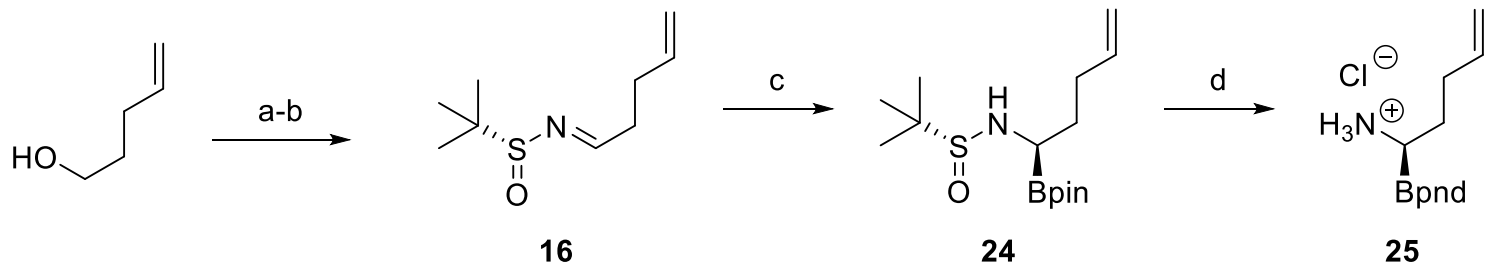

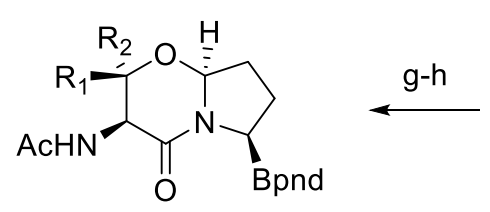

10d, $R_{1}=R_{2}=H$

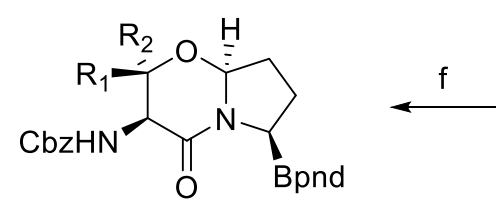

$10 c, R_{1}=R_{2}=H$ 12a, $R_{1}=M e, R_{2}=H$<smiles>[R]C([R2])(O)[C@H](NC(=O)O)C(=O)N[C@H](CCC)CCC=C</smiles>

26a, $\mathrm{R}_{1}=\mathrm{R}_{2}=\mathrm{H}$ 26b, $R_{1}=M e, R_{2}=H$
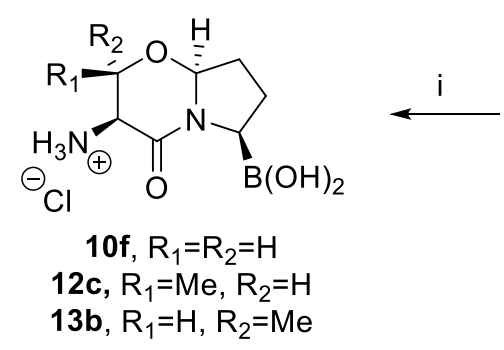

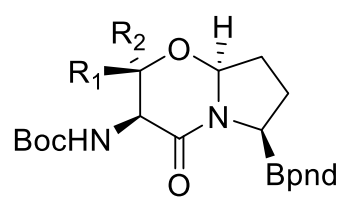<smiles>CC(C)(C)C1(C)CCCCC1</smiles><smiles>[R]C([R])(O)C(NC(=O)O)C(=O)NC(CCC=C)CCCC</smiles>

$10 \mathrm{e}, \mathrm{R}_{1}=\mathrm{R}_{2}=\mathrm{H}$ 12b, $\mathrm{R}_{1}=\mathrm{Me}, \mathrm{R}_{2}=\mathrm{H}$ 13a, $\mathrm{R}_{1}=\mathrm{H}, \mathrm{R}_{2}=\mathrm{Me}$

$27 \mathrm{a}, \mathrm{R}_{1}=\mathrm{R}_{2}=\mathrm{H}$ 27b, $\mathrm{R}_{1}=\mathrm{Me}, \mathrm{R}_{2}=\mathrm{H}$ 27c, $\mathrm{R}_{1}=\mathrm{H}, \mathrm{R}_{2}=\mathrm{Me}$<smiles></smiles><smiles>C1CCC2(CC1)CCCC2</smiles>

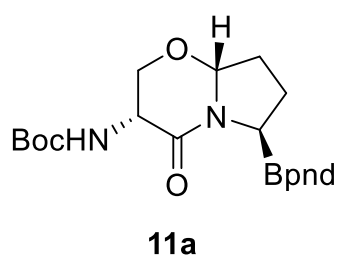<smiles>CC(C)(C)C1(C)CCCCC1</smiles>

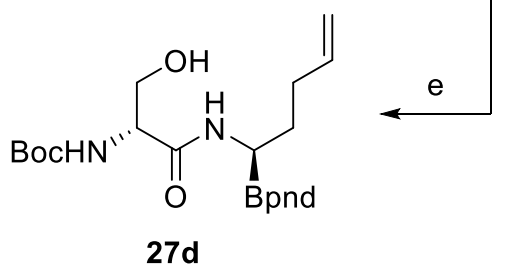

a) $(\mathrm{COCl})_{2}, \mathrm{DMSO}, \mathrm{Et}_{3} \mathrm{~N},-78^{\circ} \mathrm{C} \rightarrow \mathrm{rt}, 2 \mathrm{~h}$; b) $(R)$-(+)-tert-butyl-sulfinylamide, $\mathrm{CuSO}_{4}, \mathrm{DCM}, \mathrm{rt}, 18 \mathrm{~h}, 75 \%$ over two steps; c) $\mathrm{B}_{2} \mathrm{pin}_{2}, \mathrm{CuSO}_{4} \cdot 5 \mathrm{H}_{2} \mathrm{O}, \mathrm{PCy}_{3} \bullet \mathrm{HBF}_{4}, \mathrm{BnNH}_{2}$, Toluene- $\mathrm{H}_{2} \mathrm{O}$ 5:1, rt, 18h, 71\%, d.r. > 98:2; d) 1) (+)-pinanediol, $\mathrm{Et}_{2} \mathrm{O}, \mathrm{rt}, 24 \mathrm{~h} ; 2$ ) $\mathrm{HCl}, \mathrm{Et}_{2} \mathrm{O}, 0^{\circ} \mathrm{C}, 2 \mathrm{~h}, 44 \%$ over 2 steps; e) PyBOP, L-AA (see Experimental Section), DIPEA, $0^{\circ} \mathrm{C} \rightarrow \mathrm{rt}, 18 \mathrm{~h}, 63 \%$ (21a), 48\% (21b), 77\% (22a), 69\% (22b), 61\% (22c), 57\% (22d); f) 1) $\mathrm{O}_{3}, \mathrm{DCM} \mathrm{PPh}_{3},-78{ }^{\circ} \mathrm{C} \rightarrow \mathrm{rt}, 20 \mathrm{~h}$; 2) TFA, DCM, rt, 2h, 58\% (10c), 59\% (12a), 52\% (10e), $56 \%$ (12b), 60\% (13a), 53\% (11a); g) $\mathrm{H}_{2}, \mathrm{Pd} / \mathrm{C}, \mathrm{AcOH}, \mathrm{EtOAc}, \mathrm{rt}, 15 \mathrm{~h}$; h) AcCl, Et $3 \mathrm{~N}, \mathrm{DMAP}, 0^{\circ} \mathrm{C} \rightarrow \mathrm{rt}$, 2h, $63 \%$ over 2 steps; i) $\mathrm{BCl}_{3}, \mathrm{DCM},-78^{\circ} \mathrm{C}, 1 \mathrm{~h}, 34 \%$ (10f), $41 \%$ (12c), 52\% (13b), 39\% (11b). *pnd refers to $(+)$-pinanediol, pin refers to pinacol. 


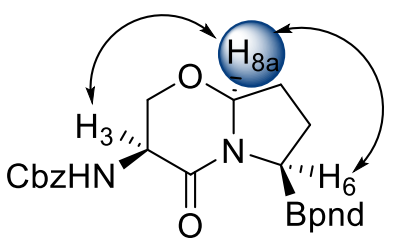

10c

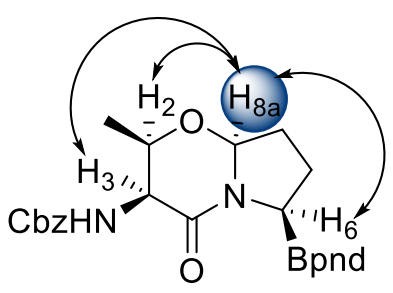

$12 a$

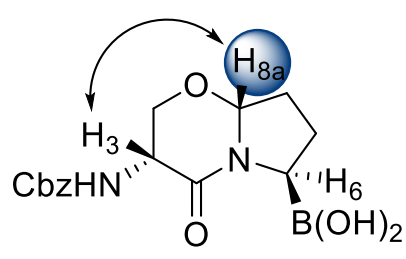

$11 \mathrm{~b}$

Figure 7. Selected nOe signals of the boron-containing bicycles.

Linear dipeptide series. As mentioned earlier, we expect that through the loss of flexibility of the dipeptide scaffold afforded by the constrained bicyclic core, this [4.3.0] alkane series would solve the problem of the cyclization of Talabostat in vivo. However, the bicycles are expected to be slightly less active than their linear counterparts, as they cannot adjust their shape to the binding site. Alternatively, reduced entropy penalty may improve their binding affinity over the more flexible Talabostat. To determine the effect of rigidification of the scaffold on biological activity, several linear dipeptide probes were also synthesized, starting from protected L- or D-Ala and LVal, the latter of which gives inhibitors resembling Talabostat. The complete list of synthesized probes can be found in Table 2 .

Table 2. Selected linear dipeptide analogues of the bicyclic series.<smiles>[R]N[C@H](C)C(=O)N1CCC[C@H]1[R2]</smiles>

23<smiles>[R]N[C@H](C)C(=O)N1CCCC1[R2]</smiles>

24<smiles>[R1]NC(C(=O)N1CCCC1[R2])C(C)C</smiles>

25

\begin{tabular}{llll}
\hline Entry & Compound & $\mathrm{R}_{1}$ & $\mathrm{R}_{2}$ \\
\hline 1 & $\mathbf{2 3 a}$ & $\mathrm{Cbz}$ & $\mathrm{H}$ \\
2 & $\mathbf{2 3 b}$ & $\mathrm{Cbz}$ & $\mathrm{CN}$ \\
3 & $\mathbf{2 3 c}$ & $\mathrm{Cbz}$ & Bpnd \\
4 & $\mathbf{2 3 d}$ & Boc & Bpnd \\
5 & $\mathbf{2 4 a}$ & Boc & Bpnd \\
6 & $\mathbf{2 5 a}$ & Cbz & Bpnd \\
7 & $\mathbf{2 5 b}$ & Boc & Bpnd \\
\hline
\end{tabular}


The synthesis of these linear analogues was rather simple. Non-covalent analogue 23a was synthesized in one step, coupling Cbz-L-Ala to pyrrolidine. The carbonitrile series was previously synthesized by our group, ${ }^{19}$ coupling readily available prolinonitrile to Cbz-L-Ala. Several boronic esters were also synthesized to probe for stereochemistry and preference of protecting group ( $\mathrm{Cbz}$ or Boc). The synthesis of these linear peptide compounds is shown in Scheme 4.

Scheme 4. Synthesis of the linear dipeptide probes. ${ }^{a}$
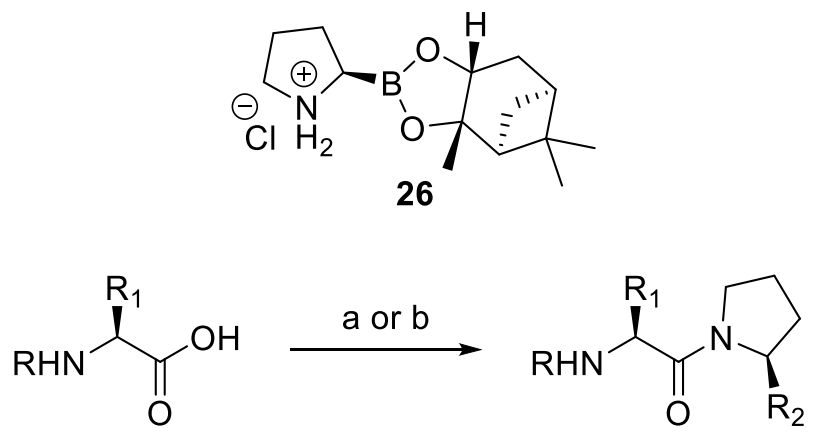

Cbz-L-Ala, $\mathrm{R}=\mathrm{Cbz}, \mathrm{R}_{1}=\mathrm{Me}$ Boc-L-Ala, $\mathrm{R}=\mathrm{Boc}, \mathrm{R}_{1}=\mathrm{Me}$ Cbz-L-Val, $\mathrm{R}=\mathrm{Cbz}, \mathrm{R}_{1}=i-\mathrm{Pr}$ Boc-L-Val, $\mathrm{R}=\mathrm{Boc}, \mathrm{R}_{1}=i-\mathrm{Pr}$

23a, $\mathrm{R}=\mathrm{Cbz}, \mathrm{R}_{1}=\mathrm{Me}, \mathrm{R}_{2}=\mathrm{H}$ 23b, $R=C b z, R_{1}=M e, R_{2}=C N$ 23c, $R=C b z, R_{1}=M e, R_{2}=B p n d$ 23d, $R=B$ oc, $R_{1}=M e, R_{2}=B p n d$ 25a, $\mathrm{R}=\mathrm{Cbz}, \mathrm{R}_{1}=i-\mathrm{Pr}, \mathrm{R}_{2}=\mathrm{Bpnd}$ 25b, R=Boc, $\mathrm{R}_{1}=i-\operatorname{Pr}, \mathrm{R}_{2}=$ Bpnd

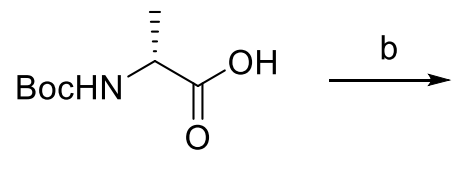

Boc-D-Ala

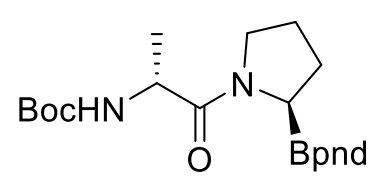

24a

a) Piv-Cl, Et ${ }_{3} \mathrm{~N}$, pyrrolidine or prolinonitrile PTSA salt (see Experimental Section), DCM, $0^{\circ} \mathrm{C} \rightarrow \mathrm{rt}, 18 \mathrm{~h}$, 49\% (23a), 59\% (23b); b) PyBOP, DIPEA, 26, DCM, $0^{\circ} \mathrm{C} \rightarrow \mathrm{rt}, 18 \mathrm{~h}, 85 \%$ (23c), 64\% (23d), 40\% (24a), $60 \%(25 \mathbf{a}), 65 \%$ (25b). *pnd refers to $(+)$-pinanediol

\section{Biological evaluations}

The non-covalent, carbonitrile, and boronic ester/acid bicyclic series were tested in vitro for inhibition of POP activity. The results of these assays can be found in 
Table 3. 
Table 3. In vitro activity of bicyclic and linear inhibitors against POP.

\begin{tabular}{|c|c|c|}
\hline Entry & Compound & POP $K_{i}(\mu \mathrm{M})$ \\
\hline 1 & $10 \mathbf{a}$ & $0.0016 \pm 0.0001$ \\
\hline 2 & $10 b$ & $4.4 \pm 1.2$ \\
\hline 3 & $10 \mathrm{c}$ & $0.0024 \pm 0.0002$ \\
\hline 4 & $10 d$ & $1.1 \pm 0.1$ \\
\hline 5 & $10 \mathrm{e}$ & $0.0068 \pm 0.0002$ \\
\hline 6 & $10 f$ & $2.2 \pm 0.5$ \\
\hline 7 & 11a & $0.34 \pm 0.03$ \\
\hline 8 & $11 b$ & $6.2 \pm 1.4$ \\
\hline 9 & $12 a$ & $0.0021 \pm 0.0001$ \\
\hline 10 & $12 b$ & $0.0049 \pm 0.0003$ \\
\hline 11 & $12 \mathrm{c}$ & $0.84 \pm 0.03$ \\
\hline 12 & $13 \mathbf{a}$ & $0.12 \pm 0.01$ \\
\hline 13 & $13 b$ & $7.2 \pm 1.2$ \\
\hline 14 & $23 \mathbf{a}$ & $53 \pm 1$ \\
\hline 15 & $23 b$ & $0.00092 \pm 0.00004$ \\
\hline 16 & $23 \mathrm{c}$ & $0.00095 \pm 0.00004$ \\
\hline 17 & 23d & $0.0013 \pm 0.00004$ \\
\hline 18 & $24 a$ & $1.0 \pm 0.2$ \\
\hline 19 & $25 a$ & $0.0015 \pm 0.0002$ \\
\hline 20 & $25 b$ & $0.0016 \pm 0.00005$ \\
\hline 21 & $1^{\mathrm{a}}$ & $0.00029 \pm 0.00004$ \\
\hline
\end{tabular}

${ }^{\mathrm{a}}$ Compound $\mathbf{1}$ was used as a positive control in the assay

The bicyclic boronic ester pro-drugs showed very potent in vitro activity against POP, with $N$ $\mathrm{Cbz}$ bicycles 10c and 12a exhibiting low single-digit nanomolar potency. This high inhibitor activity was predicted by the promising docking pose (Figure 6A/D) in which all three key ligandprotein interactions are fulfilled. Unexpectedly, the $N$-Boc derivative 10e displayed similar 
potency. Although the benzyl group is missing for aromatic interactions with Phe173, the large, greasy Boc protecting group might be compensating for this loss. The acetyl derivative 10d exhibited low micromolar activity, likely attributed to the lack of a large $N$-bound group to stabilize the inhibitor in the active site. The free amine boronic acid derivative 10 f exhibited submicromolar potency in POP. This activity can likely be attributed to the assay conditions; the $\mathrm{pH} 8.0$ basic buffer likely renders the amine neutral and allows it to act as a hydrogen bond acceptor to interact with Arg643. While, in general, nitrile and boronic acids are somewhat equipotent, boronic acids are likely to exhibit longer residence times in the active sites, ${ }^{43,54}$ making them more suitable drug candidates. As observed previously by our group, ${ }^{44}$ it is likely that the nitrile is not properly oriented to react covalently with the catalytic serine in POP, and therefore binds non-covalently. Dose-response curves of the most potent POP bicyclic inhibitors can be found in Figure 8A.

A

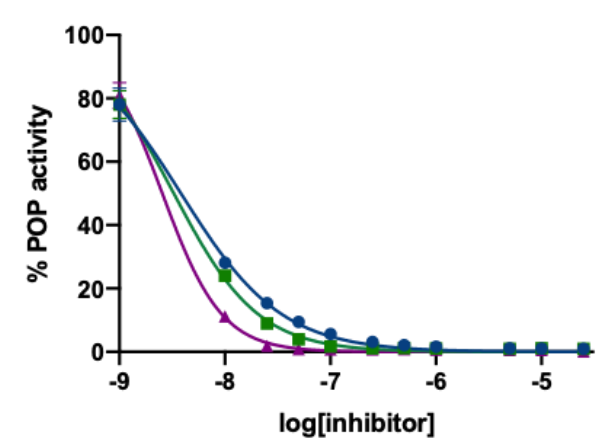

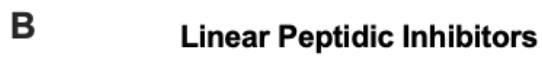

$+10 \mathrm{a}$

$\rightarrow 10 \mathrm{c}$

$-12 a$

Figure 8. Dose response curves of the most potent POP inhibitors (A) the three most potent bicyclic inhibitors; (B) the three most potent linear peptidic inhibitors

The linear peptides displayed very high potencies against POP, demonstrating single-digit nanomolar potency or sub-nanomolar activity, the latter of which are on the same order of magnitude as aldehyde control inhibitor $\mathbf{1}$ and are our most potent POP inhibitors to date. The boron-containing dipeptides' trends in activity match those of their bicyclic counterparts, with Damino acids exhibiting much lower potency than their L-amino acid analogues. Fortunately, their bicyclic analogues did not lose significant potency; L-amino acid cyclic analogues were generally in the single-digit nanomolar range. As predicted by our docking program, the designated [4.3.0] stereochemistry was optimal to inhibit the enzymes. Furthermore, the bicyclic compounds are likely to be more metabolically stable ${ }^{20,38}$ and more specific to our enzymatic targets in vivo. ${ }^{55}$ Dose-response curves comparing of our top linear peptidic inhibitors can be found in Figure 8B. 
The compounds predicted to be the most promising against FAP by docking, the $N$-acetyl bicyclic derivative and three of the free amines, were next tested against FAP. One of the Cbzcontaining bicycles was also tested on FAP and displayed no inhibitory activity (see Supporting Info), confirming the need for smaller side chains in FAP inhibitors we proposed previously. ${ }^{1}$ The results of the FAP assay are displayed in Table 4 and Figure 9. In vitro results indicate that free amine boronic acid 10f exhibits nanomolar activity in FAP and low micromolar activity in POP, making it a promising dual inhibitor for future development. However, $N$-acetyl boronic ester derivative 12c exhibits submicromolar activity in both enzymes and comparable potency to failed clinical trial candidate Talabostat against POP (Figure 1), making it a very promising drug candidate for future studies.

Table 4. In vitro activity of bicyclic dual inhibitors

\begin{tabular}{llll}
\hline Entry & Compound & POP $K_{i}(\mu \mathrm{M})$ & FAP $K_{i}(\mu \mathrm{M})$ \\
\hline 1 & $\mathbf{1 0 d}$ & $1.1 \pm 0.1$ & $1.3 \pm 0.5$ \\
2 & $\mathbf{1 0 f}$ & $2.2 \pm 0.5$ & $0.20 \pm 0.05$ \\
3 & $\mathbf{1 1 b}$ & $6.2 \pm 1.4$ & $14 \pm 2$ \\
4 & $\mathbf{1 2 c}$ & $0.84 \pm 0.03$ & $0.72 \pm 0.09$ \\
5 & Talabostat $^{\mathrm{a}}$ & $0.98 \pm 0.06$ & $0.066 \pm 0.011$ \\
\hline${ }^{\mathrm{a}}$ Values are reported as $\mathrm{IC}_{50}$ concentrations by Jansen et al $^{56}$
\end{tabular}

A

A Bicyclic Inhibitors Against POP

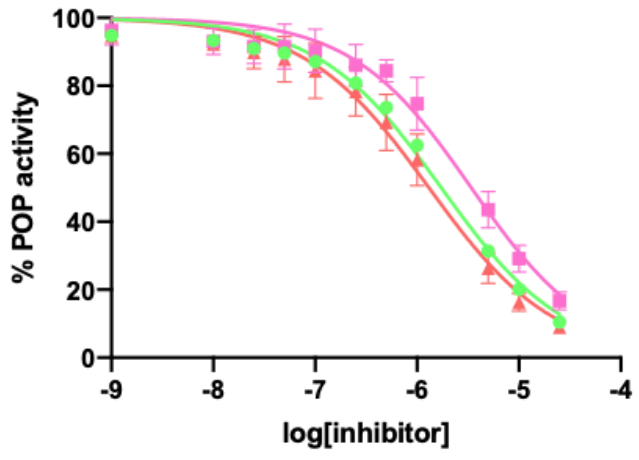

B Bicyclic Inhibitors Against FAP

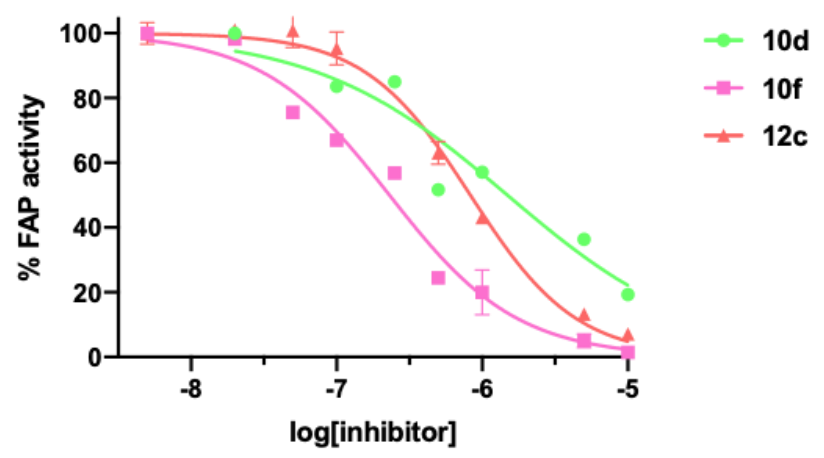

Figure 9. Dose response curves of our most potent dual inhibitors. (A) POP (B) FAP 


\section{Conclusion.}

Our group's research has previously led to potent bicycle-based POP inhibitors, revealing that the introduction of bicyclic scaffolds can enhance the metabolic stability of these inhibitors. ${ }^{20,38}$ In the shift toward POP-FAP dual inhibitors, we then aimed to improve these bicyclic scaffolds while simultaneously constraining the known inhibitor Cbz-Pro-Prolinal $\mathbf{1}$ and failed drug candidate Talabostat. Our results indicate that we were not only able to obtain potent compounds using our computationally guided optimizations of known inhibitors, but that we were able to use this method along with synthetic developments to produce an inhibitor with comparable potency to a drug that reached Phase III clinical trials. Currently, we are carrying out cell-based assays to assess the activity of our leads in cellulo, as well as performing further experiments to optimize the activity and pharmacokinetic properties of our leads including $10 \mathbf{a}, 10 \mathbf{c}$, and $12 \mathbf{a}$ as selective POP inhibitors and $\mathbf{1 0 f}$ and $\mathbf{1 2 c}$ as dual inhibitors.

\section{Experimental Section.}

In Vitro Assays. POP in vitro assays were performed as previously published by our group. $^{20,38,43}$ The POP batch used in these assays exhibited a $K_{m}$ of $141.2 \mu \mathrm{M}$ and $\mathrm{k}_{\text {cat }}$ of $21.2 \mathrm{~s}^{-1}$. The FAP assay was performed using the FAP Assay Kit from BPSBioscience. ${ }^{57}$ The FAP batch used in these assays exhibited a $K_{m}$ of $33 \mu \mathrm{M}$.

Synthesis. All commercially available reagents were used without further purification. All reactions, unless otherwise indicated, were carried out in flame-dried flasks under argon atmosphere with anhydrous solvents. FTIR spectra were recorded using a Perkin-Elmer Spectrum One FT-IR. ${ }^{1} \mathrm{H},{ }^{13} \mathrm{C}$, and ${ }^{11} \mathrm{~B}$ NMR spectra were recorded on a Bruker 400 or $500 \mathrm{MHz}$ spectrometer. Chemical shifts are reported in ppm using the residual of deuterated solvents as an internal standard. Thin layer chromatography visualization was performed by UV or by development using $\mathrm{KMnO}_{4}$, Curcumin, ninhydrin, or $p$-anisaldehyde. Chromatography was performed on silica gel 60 (230-240 mesh). High resolution mass spectrometry was performed by ESI on a Bruker Maxis Impact API QqTOF or by ESI or APCI on a ThermoFisher Exactive Plus Orbitrap-API at McGill University. Prior to biological testing, reverse-phase HPLC was used to verify the purity of compounds on an Agilent 1100 series instrument, equipped with VWDdetector, using a C18 reverse column (Agilent, Eclipse -C18 $150 \mathrm{~mm} \AA \sim 4.6 \mathrm{~mm}, 5 \mu \mathrm{m}$ ) or Zorbax 
(ZORBAX Bonus-RP, 80Å, $4.6 \times 150 \mathrm{~mm}, 5 \mu \mathrm{m}$ ) with UV detection at 220 or $215 \mathrm{~nm}$. All tested compounds were at least $95 \%$ pure. All compounds were stored at $-20^{\circ} \mathrm{C}$.

(S)-2-methyl- $N$-(pent-4-en-1-yl)propane-2-sulfinamide (15) and (R)-2-methyl- $N$-(pent-4en-1-ylidene)propane-2-sulfinamide (15a) (general procedure for both; the two sulfinimines are spectrally identical) Oxalyl chloride (1.2 eq) was dissolved in DCM (1.5 M) under Ar, and the solution was cooled to $-78^{\circ} \mathrm{C}$. DMSO (2.5 eq) in DCM (7 M) was added slowly. The solution stirred for 5 minutes. 4-penten-1-ol (1 eq) in DCM (3 M) was added slowly, and the reaction stirred for 15 minutes. Triethylamine ( 3 eq) was added slowly, and the reaction stirred for 2 hours at room temperature. Water was added, and the product was extracted with DCM. The combined organic layers were washed with $1 \mathrm{M} \mathrm{HCl}$, saturated $\mathrm{NaHCO}_{3}$, and brine, dried over $\mathrm{Na}_{2} \mathrm{SO}_{4}$, filtered and concentrated in vacuo at $650 \mathrm{mbar}, 40^{\circ} \mathrm{C}$. (Some solvent remains; product is volatile.) The resultant 4-pentenal (assume 100\% yield) was dissolved in anhydrous DCM (0.5 M), and $(R)-(+)-2-$ methyl2-propanesulfinamide (1 eq) [or the (S)-(-) enantiomer for the synthesis of the (S)-sulfinimine] and anhydrous CuSO4 (3 eq) were added. The reaction stirred at room temperature overnight. The mixture was then filtered through a pad of Celite ${ }^{\circledR}$, and the filter cake was rinsed with DCM. The filtrate was concentrated in vacuo to give a brown liquid, which was purified by flash chromatography on a silica gel column $(85: 15$ hexanes-EtOAc) to give a yellow liquid (15 62\%, 15a 75\%). $R_{f}=0.45\left(85: 15\right.$ hexanes-EtOAc); ${ }^{1} \mathrm{H}$ NMR $(500 \mathrm{MHz}$, Chloroform- $d) \delta 8.07(\mathrm{t}, J=$ $4.4 \mathrm{~Hz}, 1 \mathrm{H}), 5.83$ (ddt, $J=16.8,10.2,6.5 \mathrm{~Hz}, 1 \mathrm{H}), 5.07$ (dq, $J=17.2,1.7 \mathrm{~Hz}, 1 \mathrm{H}), 5.02$ (dq, $J=$ $10.2,1.5 \mathrm{~Hz}, 1 \mathrm{H}), 2.62(\mathrm{td}, J=7.3,4.4 \mathrm{~Hz}, 2 \mathrm{H}), 2.42-2.36(\mathrm{~m}, 2 \mathrm{H}), 1.18(\mathrm{~s}, 9 \mathrm{H}) .{ }^{13} \mathrm{C} \mathrm{NMR}(126$ MHz, Chloroform- $d$ ) $\delta 168.94,136.80,115.97,56.69,35.41,29.49,22.49$. Spectral and physical data were in accordance with the literature. ${ }^{58,59}$

$(S)-N$-((S)-1-cyanopent-4-en-1-yl)-2-methylpropane-2-sulfinamide (16) Imine 15 (462 mg, 1 eq) was dissolved in DCM (24 mL), and Gd(OTf) 3 (298 mg, 0.2 eq) and TMSCN (489 mg, 0.62 $\mathrm{mL}, 2$ eq) were added. The reaction stirred for $48 \mathrm{~h}$ at room temperature and was quenched with saturated $\mathrm{NaHCO}_{3}$. The product was extracted with $\mathrm{DCM}$, and the combined organic layers were washed with brine, dried over $\mathrm{Na}_{2} \mathrm{SO}_{4}$, and concentrated in vacuo to give the crude product as a brown oil, which was purified by flash chromatography on a silica gel column (eluent 70:30 hexanes-EtOAc) to give the product as a yellow oil $(318 \mathrm{mg}, 60 \%) . R_{f}=0.50(70: 30$ EtOAchexanes); IR (film) $\mathrm{cm}^{-1} 3187,3083,2960,2238,1641,1391,1366,1062,911 ;{ }^{1} \mathrm{H}$ NMR (500 
MHz, Chloroform- $d$ ) $\delta 5.84-5.69(\mathrm{~m}, 1 \mathrm{H}), 5.16-5.06(\mathrm{~m}, 2 \mathrm{H}), 4.23-4.09(\mathrm{~m}, 1 \mathrm{H}), 3.93-3.63$ (m, 1H), $2.37-2.21(\mathrm{~m}, 2 \mathrm{H}), 2.15-1.89(\mathrm{~m}, 2 \mathrm{H}), 1.24(\mathrm{~s}, 9 \mathrm{H}) ;{ }^{13} \mathrm{C}$ NMR $(126 \mathrm{MHz}$, Chloroformd) $\delta 22.61$ (3C), 29.47, 34.01, 45.69, 57.21, 117.28, 119.19, 135.69; HRMS (ESI+) $\mathrm{m} / z$ calcd for $\left[\mathrm{C}_{10} \mathrm{H}_{18} \mathrm{ON} \mathrm{ON}_{2} \mathrm{~S}+\mathrm{Na}\right]^{+}$237.1032, found 237.1035.

(S)-1-cyanopent-4-en-1-aminium chloride (17) Sulfinamide 16 (298 mg, 1 eq) was dissolved in $\mathrm{Et}_{2} \mathrm{O}(12 \mathrm{~mL})$, and the solution was cooled to $0^{\circ} \mathrm{C}$. $\mathrm{HCl}\left(2 \mathrm{M}^{\text {in }} \mathrm{Et}_{2} \mathrm{O}, 2.1 \mathrm{~mL}, 3 \mathrm{eq}\right)$ was added dropwise, and the resultant mixture stirred for $1 \mathrm{~h}$ at $0^{\circ} \mathrm{C}$. The solvent was removed in vacuo to give the product as a while solid, which was taken to the next step without purification (136 mg, quant.) $R_{f}=$ does not elute on silica-backed TLC plates; $\mathrm{mp}=94-97^{\circ} \mathrm{C}$; IR (neat) $\mathrm{cm}^{-1} 3071,2956$, 1643, 1483, 1185, 926; ${ }^{1} \mathrm{H}$ NMR (400 MHz, Methanol- $\left.d_{4}\right) \delta 5.86$ (dddd, $J=17.2,10.2,7.1,6.1$ $\mathrm{Hz}, 1 \mathrm{H}), 5.18(\mathrm{dq}, J=17.1,1.6 \mathrm{~Hz}, 1 \mathrm{H}), 5.11$ (dq, $J=10.2,1.3 \mathrm{~Hz}, 1 \mathrm{H}), 4.56-4.35$ (m, 1H), 2.45 $-2.22(\mathrm{~m}, 2 \mathrm{H}), 2.11-2.00(\mathrm{~m}, 2 \mathrm{H}) ;{ }^{13} \mathrm{C}$ NMR (101 MHz, Methanol- $\left.d_{4}\right) \delta$ 30.23, 31.26, 42.23, 116.62, 117.59, 136.33; HRMS (ESI+) $m / z$ calcd for $\left[\mathrm{C}_{6} \mathrm{H}_{11} \mathrm{~N}_{2}\right]^{+} 111.0917$, found 111.0922 .

\section{(R)-2-methyl- $N$-((R)-1-(4,4,5,5-tetramethyl-1,3,2-dioxaborolan-2-yl)pent-4-en-1-}

yl)propane-2-sulfinamide (19) Tricyclohexylphosphonium tetrafluoroborate (63 mg, $0.1 \mathrm{eq}$ ) was dissolved in toluene $(2.1 \mathrm{~mL})$, and the solution was stirred rapidly. Copper (II) sulfate pentahydrate (43 mg, $0.1 \mathrm{eq}$ ) and water $(0.9 \mathrm{~mL})$ were added, turning the reaction light blue. Benzylamine (37 $\mathrm{mg}, 0.2 \mathrm{eq}$ ) was added, turning the mixture dark blue. The mixture stirred at room temperature for 10 minutes, and was then cooled to $0^{\circ} \mathrm{C}$. The sulfinylimine $15 \mathrm{a}(320 \mathrm{mg}, 1 \mathrm{eq})$ in toluene $(2.1 \mathrm{~mL})$ was added, followed by $\mathrm{B}_{2} \mathrm{pin}_{2}(651 \mathrm{mg}, 1.5 \mathrm{eq})$, and the reaction mixture turned turquoise. The reaction was kept at $0^{\circ} \mathrm{C}$ for 15 minutes, then was warmed to room temperature and stirred overnight, after which the reaction turned dark brown. The mixture was diluted with ethyl acetate and quenched with saturated $\mathrm{NaHCO}_{3}$. The biphasic mixture stirred for 30 minutes. The product was then extracted from the aqueous layer with ethyl acetate, and the organic layer was washed with saturated $\mathrm{NH}_{4} \mathrm{Cl}$, saturated $\mathrm{NaHCO}_{3}$ (copiously) and brine, dried over $\mathrm{Na}_{2} \mathrm{SO}_{4}$, and concentrated in vacuo to give the crude product as a brown oil, which was clarified with charcoal to give a clear oil (385 mg, 71\%). $R_{f}=$ streaks on regular silica; IR (film) $\mathrm{cm}^{-1} 3206,3079,2976$, 1639, 1380, 1370, 1332, 1142, 1058, 910; ${ }^{1} \mathrm{H}$ NMR (500 MHz, Chloroform- $d$ ) $\delta 5.73$ (ddt, $J=$ $16.9,10.2,6.7 \mathrm{~Hz}, 1 \mathrm{H}), 4.96(\mathrm{dq}, J=17.1,1.7 \mathrm{~Hz}, 1 \mathrm{H}), 4.88$ (dq, $J=10.1,1.4 \mathrm{~Hz}, 1 \mathrm{H}), 3.16$ (d, $J$ $=7.0 \mathrm{~Hz}, 1 \mathrm{H}), 2.97(\mathrm{q}, J=7.0 \mathrm{~Hz}, 1 \mathrm{H}), 2.07(\mathrm{~m}, 2 \mathrm{H}), 1.77-1.64(\mathrm{~m}, 2 \mathrm{H}), 1.18(\mathrm{~s}, 6 \mathrm{H}), 1.17(\mathrm{~s}$, 
6H), $1.11(\mathrm{~s}, 9 \mathrm{H}) ;{ }^{13} \mathrm{C}$ NMR (126 MHz, Chloroform- $d$ ) $\delta 22.52$ (3C), $24.52(2 \mathrm{C}), 24.92(2 \mathrm{C})$, 31.01, 32.66, 42.75, 55.97, 84.00 (2C), 115.07, 138.01; ${ }^{11} \mathrm{~B}$ NMR (161 MHz, Chloroform- $d$ ) $\delta$ 32.41; HRMS (ESI+) $m / z$ calcd for $\left[\mathrm{C}_{15} \mathrm{H}_{30} \mathrm{O}_{3} \mathrm{NSB}+\mathrm{Na}\right]^{+} 338.1932$, found 338.1931 .

\section{(R)-1-((3aS,4S,6S,7aR)-3a,5,5-trimethylhexahydro-4,6-}

methanobenzo $[d][1,3,2]$ dioxaborol-2-yl)pent-4-en-1-aminium chloride (20) The aminoboronic ester 19 (11.51 g, 1 eq) was dissolved in $\mathrm{Et}_{2} \mathrm{O}(120 \mathrm{~mL})$, and (+)-pinanediol (6.22 $\mathrm{g}, 1$ eq) was added. The solution stirred at room temperature for 24 hours. The solvent was removed in vacuo, the residue was re-dissolved in $\mathrm{Et}_{2} \mathrm{O}(75 \mathrm{~mL})$, and the solution was cooled to $0^{\circ} \mathrm{C}$. $\mathrm{HCl}$ $\left(2 \mathrm{M}\right.$ in $\mathrm{Et}_{2} \mathrm{O}, 24 \mathrm{~mL}, 1.3 \mathrm{eq}$ ) was added dropwise, and the argon balloon was removed. After $2 \mathrm{~h}$ of stirring at room temperature, the solvent was removed in vacuo to give a white solid, which was triturated at $0^{\circ} \mathrm{C}$ in 2:1 $n$-hexane/ $/ \mathrm{Et}_{2} \mathrm{O}$ and filtered, rinsing with cold $2: 1 n$-hexane $/ \mathrm{Et}_{2} \mathrm{O}$, to give the boroamine salt 20 as a fluffy white solid ( $4.85 \mathrm{~g}, 44 \%$ over 2 steps). $R_{f}=$ does not elute on silica-backed TLC plates; $\mathrm{mp}=168-171^{\circ} \mathrm{C}$; IR (film) $\mathrm{cm}^{-1} 3130,2921,1605,1405,1389,1076$, 1029; ${ }^{1} \mathrm{H}$ NMR (500 MHz, Chloroform- $d$ ) $\delta 8.31$ (s, br, 3H), 5.78 (ddt, $\left.J=16.6,11.1,6.0 \mathrm{~Hz}, 1 \mathrm{H}\right)$, $5.13(\mathrm{~d}, J=16.9 \mathrm{~Hz}, 1 \mathrm{H}), 4.99$ (d, $J=10.0 \mathrm{~Hz}, 1 \mathrm{H}), 4.38$ (d, $J=8.2 \mathrm{~Hz}, 1 \mathrm{H}), 2.97$ (s, br, 1H), 2.43 $-2.14(\mathrm{~m}, 4 \mathrm{H}), 2.16-1.95(\mathrm{~m}, 3 \mathrm{H}), 1.98-1.88(\mathrm{~m}, 2 \mathrm{H}), 1.41(\mathrm{~s}, 3 \mathrm{H}), 1.27$ (s, 3H), 1.17 (d, $J=$ $10.9 \mathrm{~Hz}, 1 \mathrm{H}), 0.81(\mathrm{~s}, 3 \mathrm{H}) ;{ }^{13} \mathrm{C} \mathrm{NMR}\left(126 \mathrm{MHz}, \mathrm{CDCl}_{3}\right) \delta 24.08,26.71,27.13,28.61,29.04$, $30.71,35.17,37.12,38.25,39.57,51.21,77.16,78.88,87.74,116.27,137.12 ;{ }^{11}$ B NMR $(161 \mathrm{MHz}$, $\left.\mathrm{CDCl}_{3}\right) \delta 32.35$; HRMS (APCI+) $\mathrm{m} / z$ calcd for $\left[\mathrm{C}_{15} \mathrm{H}_{26} \mathrm{O}_{2} \mathrm{NB}+\mathrm{H}\right]^{+} 264.2129$, found 264.2129.

General peptide coupling procedure A. The protected amino acid (1 eq) was suspended in DCM $(0.1 \mathrm{M})$, and $\mathrm{HOBt} \cdot \mathrm{H}_{2} \mathrm{O}(1.2 \mathrm{eq})$ was added, followed by $\mathrm{EDC} \cdot \mathrm{HCl}(1.2 \mathrm{eq})$. The reaction stirred at $0^{\circ} \mathrm{C}$ for $1 \mathrm{~h}$. The amine salt $(1 \mathrm{eq})$ was then added, followed by $\mathrm{Et}_{3} \mathrm{~N}(3 \mathrm{eq})$. The reaction stirred at $0^{\circ} \mathrm{C}$ for $1 \mathrm{~h}$, then at room temperature overnight. Water was added, and the product was extracted with DCM. The combined organic layers were washed with saturated $\mathrm{NH}_{4} \mathrm{Cl}$, saturated $\mathrm{NaHCO}_{3}$, and brine, dried over $\mathrm{Na}_{2} \mathrm{SO}_{4}$, filtered, and concentrated in vacuo to give the crude product. The crude material was purified by flash chromatography on a silica gel column to give the corresponding dipeptide.

General peptide coupling procedure B. The protected amino acid (1 eq) was suspended in $\mathrm{DCM}(0.1 \mathrm{M})$, and $\mathrm{Et}_{3} \mathrm{~N}$ (5 eq) was added, followed by Piv-Cl $(1.1 \mathrm{eq})$. The reaction stirred at $0^{\circ} \mathrm{C}$ for $1 \mathrm{~h}$. The amine salt $(1 \mathrm{eq})$ was then added. The reaction stirred at $0^{\circ} \mathrm{C}$ for $1 \mathrm{~h}$, then at room 
temperature overnight. Water was added, and the product was extracted with DCM. The combined organic layers were washed with saturated $\mathrm{NH}_{4} \mathrm{Cl}$, saturated $\mathrm{NaHCO}_{3}$, and brine, dried over $\mathrm{Na}_{2} \mathrm{SO}_{4}$, filtered, and concentrated in vacuo to give the crude product. The crude material was purified by flash chromatography on a silica gel column to give the corresponding dipeptide.

General peptide coupling procedure C. The protected amino acid (1 eq) was suspended in $\operatorname{DCM}(0.1 \mathrm{M})$, and PyBOP (1.2 eq) was added, followed by the amine (1 eq), then DIPEA (3 eq). The reaction stirred at $0^{\circ} \mathrm{C}$ for $1 \mathrm{~h}$, then at room temperature overnight. Water was added, and the product was extracted with DCM. The combined organic layers were washed with saturated $\mathrm{NH}_{4} \mathrm{Cl}$, saturated $\mathrm{NaHCO}_{3}$, and brine, dried over $\mathrm{Na}_{2} \mathrm{SO}_{4}$, filtered, and concentrated in vacuo to give the crude product. The crude material was purified by flash chromatography on a silica gel column to give the corresponding dipeptide.

General peptide coupling procedure D. The protected amino acid (1 eq) was dissolved in DMF $(0.3 \mathrm{M})$, and the solution was cooled to $0^{\circ} \mathrm{C}$. HATU $(1.2 \mathrm{eq})$ was added, followed by the amine (1 eq), then $\mathrm{Et}_{3} \mathrm{~N}$ (10 eq). The reaction stirred at room temperature overnight. Water was added, and the product was extracted with DCM. The combined organic layers were washed with saturated $\mathrm{NH}_{4} \mathrm{Cl}$, saturated $\mathrm{NaHCO}_{3}$, and brine, dried over $\mathrm{Na}_{2} \mathrm{SO}_{4}$, filtered, and concentrated in vacuo to give the crude product. The crude material was purified by flash chromatography on a silica gel column to give the corresponding dipeptide.

\section{Benzyl (S)-(3-hydroxy-1-oxo-1-(pent-4-en-1-ylamino)propan-2-yl)carbamate}

(14).

Dipeptide 14 was prepared following general peptide coupling procedure A, using Z-L-Ser as the amino acid and readily available 5-amino-1-pentene trifluoroacetate (Supporting Information) as the amine. The crude product was purified by flash chromatography on a silica gel column (eluent 70:30 EtOAc-hexanes) to give the product as a white solid $(78 \%) . R_{f}=0.43(80: 20$ EtOAchexanes); $\mathrm{mp}=143-145^{\circ} \mathrm{C}$; IR (film) $\mathrm{cm}^{-1} 3316,3068,2937,1709,1651,1532,1239,1060,913$; ${ }^{1} \mathrm{H}$ NMR (500 MHz, Chloroform-d) $\delta 7.39-7.30(\mathrm{~m}, 5 \mathrm{H}), 6.64(\mathrm{~s}, 1 \mathrm{H}), 5.87$ (d, J= $\left.7.6 \mathrm{~Hz}, 1 \mathrm{H}\right)$, $5.77(\mathrm{ddt}, J=16.9,10.2,6.6 \mathrm{~Hz}, 1 \mathrm{H}), 5.13(\mathrm{~s}, 2 \mathrm{H}), 5.02(\mathrm{dq}, J=17.2,1.7 \mathrm{~Hz}, 1 \mathrm{H}), 4.98(\mathrm{dq}, J=$ 10.2, $1.4 \mathrm{~Hz}, 1 \mathrm{H}), 4.17$ (ddd, $J=7.8,4.9,3.2 \mathrm{~Hz}, 1 \mathrm{H}), 4.15-4.05(\mathrm{~m}, 1 \mathrm{H}), 3.71-3.60$ (m, 1H), $3.25(\mathrm{q}, J=6.7 \mathrm{~Hz}, 2 \mathrm{H}), 3.20(\mathrm{~s}, 1 \mathrm{H}), 2.06(\mathrm{q}, J=7.2 \mathrm{~Hz}, 2 \mathrm{H}), 1.59(\mathrm{p}, J=7.3 \mathrm{~Hz}, 2 \mathrm{H}) ;{ }^{13} \mathrm{C} \mathrm{NMR}$ (126 MHz, Chloroform-d) $\delta 28.58,31.09,39.15,55.29,62.91,67.51,115.55,128.23$ (2C), 128.50, 
$128.74(2 \mathrm{C}), 136.06,137.64,156.93,171.00 ; \mathrm{HRMS}(\mathrm{ESI}+) \mathrm{m} / z$ calcd for $\left[\mathrm{C}_{16} \mathrm{H}_{22} \mathrm{O}_{4} \mathrm{~N}_{2}+\mathrm{Na}\right]^{+}$ 329.1472 , found 329.1464 .

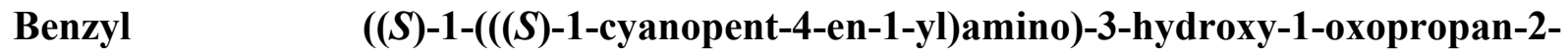

yl)carbamate (18). The product was synthesized following general coupling procedure D, using 17 as the amine. The crude product was purified by silica gel (eluent 60:40 EtOAc-hexanes) to give the product as a white foam $(80 \%) . R_{f}=0.27$ (60:40 EtOAc-hexanes); $\mathrm{mp}=87-91^{\circ} \mathrm{C}$; IR (film) $\mathrm{cm}^{-1} 3409,3321,3278,3020,2940,1707,1671,1516,1217,1058 ;{ }^{1} \mathrm{H}$ NMR (500 MHz, Acetone- $\left.d_{6}\right) \delta 8.20-7.95(\mathrm{~m}, 1 \mathrm{H}), 7.47-7.18(\mathrm{~m}, 5 \mathrm{H}), 6.48(\mathrm{~d}, J=8.7 \mathrm{~Hz}, 1 \mathrm{H}), 5.82(\mathrm{ddt}, J=$ 17.0, 10.1, 6.7 Hz, 1H), 5.15 - 5.04 (m, 3H), 5.01 (dq, $J=10.2,1.3 \mathrm{~Hz}, 1 \mathrm{H}), 4.33-4.18$ (m, 2H), $3.87(\mathrm{dt}, J=10.3,5.0 \mathrm{~Hz}, 1 \mathrm{H}), 3.81$ (dt, $J=10.7,5.2 \mathrm{~Hz}, 1 \mathrm{H}), 2.23$ (q, $J=7.4 \mathrm{~Hz}, 2 \mathrm{H}), 2.01-$ $1.91(\mathrm{~m}, 2 \mathrm{H}) ;{ }^{13} \mathrm{C}$ NMR (126 MHz, Acetone- $\left.d_{6}\right) \delta 30.09,32.56,40.53,57.85,62.99,67.01,116.59$, $119.55,128.70(2 \mathrm{C}), 128.71,129.24$ (2C), 137.34, 137.98, 157.01, 171.22; HRMS (ESI+) $\mathrm{m} / z$ calcd for $\left[\mathrm{C}_{17} \mathrm{H}_{21} \mathrm{O}_{4} \mathrm{~N}_{3}+\mathrm{Na}\right]^{+}$354.1424, found 354.1417 .

\section{Benzyl ((S)-3-hydroxy-1-oxo-1-(((R)-1-((3aS,4S,6S,7aR)-3a,5,5-trimethylhexahydro-4,6-} methanobenzo $[d][1,3,2]$ dioxaborol-2-yl)pent-4-en-1-yl)amino)propan-2-yl)carbamate (21a).

The product was synthesized following general coupling procedure $\mathrm{C}$, using 20 as the amine. The crude product was purified by silica gel (eluent 60:40 EtOAc-hexanes) to give the product as a white foam (63\%). $R_{f}=0.23$ (50:50 EtOAc-hexanes); IR (neat) $\mathrm{cm}^{-1} 3310,3071,2929,1722,1701$, 1522, 1385, 1372, 1247, 1078, 1052, 906; ${ }^{1} \mathrm{H}$ NMR (500 MHz, Acetone- $\left.d_{6}\right) \delta 8.04$ (s, 1H), $7.46-$ $7.21(\mathrm{~m}, 5 \mathrm{H}), 6.63-6.43(\mathrm{~m}, 1 \mathrm{H}), 5.82(\mathrm{ddt}, J=17.0,10.3,6.7 \mathrm{~Hz}, 1 \mathrm{H}), 5.10$ (s, 2H), 4.99 (dq, $J$ $=17.1,1.8 \mathrm{~Hz}, 1 \mathrm{H}), 4.91(\mathrm{ddt}, J=10.2,2.2,1.2 \mathrm{~Hz}, 1 \mathrm{H}), 4.44-4.35(\mathrm{~m}, 1 \mathrm{H}), 4.31$ (dt, $J=7.9$, $5.1 \mathrm{~Hz}, 1 \mathrm{H}), 4.24(\mathrm{dd}, J=8.8,2.2 \mathrm{~Hz}, 1 \mathrm{H}), 3.85$ (dt, $J=10.8,5.3 \mathrm{~Hz}, 1 \mathrm{H}), 3.77$ (dt, $J=11.3,5.8$ $\mathrm{Hz}, 1 \mathrm{H}), 2.84$ (ddd, $J=7.8,6.3,4.3 \mathrm{~Hz}, 1 \mathrm{H}), 2.31$ (ddt, $J=13.9,8.7,2.5 \mathrm{~Hz}, 1 \mathrm{H}), 2.22-2.09$ (m, $3 \mathrm{H}), 1.94(\mathrm{t}, J=5.6 \mathrm{~Hz}, 1 \mathrm{H}), 1.84(\mathrm{tt}, J=5.9,3.0 \mathrm{~Hz}, 1 \mathrm{H}), 1.78(\mathrm{ddd}, J=14.2,3.2,2.1 \mathrm{~Hz}, 1 \mathrm{H})$, $1.73-1.64(\mathrm{~m}, 1 \mathrm{H}), 1.64-1.57(\mathrm{~m}, 1 \mathrm{H}), 1.48-1.40(\mathrm{~m}, 1 \mathrm{H}), 1.34(\mathrm{~s}, 3 \mathrm{H}), 1.27(\mathrm{~s}, 3 \mathrm{H}), 0.86(\mathrm{~s}$, $3 \mathrm{H}) ;{ }^{13} \mathrm{C}$ NMR (126 MHz, Acetone- $\left.d_{6}\right) \delta 24.35,26.98,27.56,29.25,31.32,32.08,36.74,38.77$, $39.73,40.62,52.70,56.55,63.10,66.99,77.75,85.09,114.89,128.62$ (2C), 128.65, 129.19 (2C), 137.96, 139.69, 156.93, 173.39; ${ }^{11} \mathrm{~B}$ NMR (161 MHz, Acetone-d6) $\delta$ 26.64; HRMS (APCI+) m/z calcd for $\left[\mathrm{C}_{26} \mathrm{H}_{37} \mathrm{O}_{6} \mathrm{~N}_{2} \mathrm{~B}+\mathrm{Na}\right]^{+}$507.2637, found 507.2652. 


\section{Benzyl ((2S,3R)-3-hydroxy-1-oxo-1-(( $R)-1-((3 a S, 4 S, 6 S, 7 \mathrm{a} R)-3 \mathrm{a}, 5,5-$ trimethylhexahydro-}

\section{4,6-methanobenzo $[d][1,3,2]$ dioxaborol-2-yl)pent-4-en-1-yl)amino)butan-2-yl)carbamate}

(21b). The product was synthesized following general coupling procedure $C$, using 20 as the

amine. The crude product was purified by silica gel (eluent 60:40 EtOAc-hexanes) to give the product as a white solid (48\%). $R_{f}=0.38$ (50:50 EtOAc-hexanes); $\mathrm{mp}=44-47^{\circ} \mathrm{C}$; IR (film) $\mathrm{cm}^{-1}$ 3322, 3068, 2922, 1722, 1699, 1606, 1515, 1383, 1373, 1247, 1120, 1070, 908; ${ }^{1} \mathrm{H}$ NMR (500 MHz, Acetone-d $\left.d_{6}\right) \quad 7.91(\mathrm{~s}, 1 \mathrm{H}), 7.43-7.28(\mathrm{~m}, 5 \mathrm{H}), 6.25(\mathrm{~d}, J=8.2 \mathrm{~Hz}, 1 \mathrm{H}), 5.82(\mathrm{ddt}, J=17.0$, 10.2, $6.7 \mathrm{~Hz}, 1 \mathrm{H}), 5.11$ (s, 2H), 4.99 (dq, $J=17.2,1.7 \mathrm{~Hz}, 1 \mathrm{H}), 4.91$ (ddt, $J=10.1,2.3,1.2 \mathrm{~Hz}$, $1 \mathrm{H}), 4.30(\mathrm{~d}, J=4.3 \mathrm{~Hz}, 1 \mathrm{H}), 4.25(\mathrm{dd}, J=8.8,2.2 \mathrm{~Hz}, 1 \mathrm{H}), 4.22-4.13(\mathrm{~m}, 2 \mathrm{H}), 2.87-2.81(\mathrm{~m}$, 1H), 2.31 (ddt, $J=14.0,8.8,2.5 \mathrm{~Hz}, 1 \mathrm{H}), 2.21-2.07(\mathrm{~m}, 3 \mathrm{H}), 1.95(\mathrm{dd}, J=11.1,5.6 \mathrm{~Hz}, 1 \mathrm{H})$, $1.84(\mathrm{tq}, J=6.0,3.1 \mathrm{~Hz}, 1 \mathrm{H}), 1.81-1.74(\mathrm{~m}, 1 \mathrm{H}), 1.74-1.65(\mathrm{~m}, 1 \mathrm{H}), 1.65-1.44(\mathrm{~m}, 1 \mathrm{H}), 1.45$ - $1.37(\mathrm{~m}, 1 \mathrm{H}), 1.34(\mathrm{~s}, 3 \mathrm{H}), 1.27(\mathrm{~s}, 3 \mathrm{H}), 1.22-1.15(\mathrm{~m}, 3 \mathrm{H}), 0.86(\mathrm{~s}, 3 \mathrm{H}) ;{ }^{13} \mathrm{C} \mathrm{NMR}(126 \mathrm{MHz}$, Acetone- $\left.d_{6}\right) \delta 19.59,24.36,26.99,27.56,29.25,31.32,32.14,36.72,38.80,39.44,40.62,52.69$, 59.82, 67.00, 67.96, 77.85, 85.23, 114.93, 128.57 (2C), 128.66, 129.21 (2C), 138.04, 139.64, 157.12, 173.17; ${ }^{11} \mathrm{~B}$ NMR (161 MHz, Acetone-d6) $\delta$ 27.32; HRMS (ESI+) $\mathrm{m} / z$ calcd for $\left[\mathrm{C}_{27} \mathrm{H}_{39} \mathrm{O}_{6} \mathrm{~N}_{2} \mathrm{~B}+\mathrm{Na}\right]^{+}$521.2793, found 521.2804.

tert-Butyl ((S)-3-hydroxy-1-oxo-1-(( $R)-1-((3 \mathrm{a} S, 4 S, 6 S, 7 \mathrm{a} R)-3 \mathrm{a}, 5,5-$ trimethylhexahydro4,6-methanobenzo $[d][1,3,2]$ dioxaborol-2-yl)pent-4-en-1-yl)amino)propan-2-yl)carbamate (22a). The product was synthesized following general coupling procedure $C$, using Boc-L-Ser as the amino acid and 20 as the amine. The crude product was purified by silica gel (eluent 70:30 EtOAc-hexanes) to give the product as a white solid (77\%). $R_{f}=0.23$ (60:40 hexanes-EtOAc); mp $=49-52^{\circ} \mathrm{C}$; IR (film) $\mathrm{cm}^{-1} 3425,3345,3079,3020,2980,1709,1653,1607,1504,1389,1368$, 1215, 1167, 1054; ${ }^{1} \mathrm{H}$ NMR (400 MHz, Acetone- $\left.d_{6}\right) \delta 7.87(\mathrm{~s}, 1 \mathrm{H}), 6.04(\mathrm{~d}, J=8.4 \mathrm{~Hz}, 1 \mathrm{H}), 5.83$ (ddt, $J=17.0,10.2,6.7 \mathrm{~Hz}, 1 \mathrm{H}), 5.00$ (dq, $J=17.1,1.7 \mathrm{~Hz}, 1 \mathrm{H}), 4.91$ (ddt, $J=10.2,2.4,1.2 \mathrm{~Hz}$, $1 \mathrm{H}), 4.25(\mathrm{dd}, J=8.7,2.2 \mathrm{~Hz}, 1 \mathrm{H}), 4.23-4.15(\mathrm{~m}, 2 \mathrm{H}), 3.82(\mathrm{dt}, J=11.0,5.5 \mathrm{~Hz}, 1 \mathrm{H}), 3.77-$ $3.68(\mathrm{~m}, 1 \mathrm{H}), 2.88-2.78(\mathrm{~m}, 1 \mathrm{H}), 2.31(\mathrm{ddt}, J=13.9,8.8,2.5 \mathrm{~Hz}, 1 \mathrm{H}), 2.21-2.07$ (m, 3H), 2.00 $-1.91(\mathrm{~m}, 1 \mathrm{H}), 1.85$ (tt, $J=5.7,3.0 \mathrm{~Hz}, 1 \mathrm{H}), 1.78(\mathrm{ddd}, J=14.2,3.3,2.2 \mathrm{~Hz}, 1 \mathrm{H}), 1.75-1.65(\mathrm{~m}$, $1 \mathrm{H}), 1.65-1.56(\mathrm{~m}, 1 \mathrm{H}), 1.42(\mathrm{~s}, 9 \mathrm{H}), 1.34(\mathrm{~s}, 3 \mathrm{H}), 1.27(\mathrm{~s}, 3 \mathrm{H}), 0.86(\mathrm{~s}, 3 \mathrm{H}) ;{ }^{13} \mathrm{C} \mathrm{NMR}(101$ $\mathrm{MHz}$, Acetone- $\left.d_{6}\right) \delta 23.48,26.13,26.70,27.64$ (3C), 28.41, 30.55, 31.22, 35.89, 37.92, 38.45, $39.76,51.85,55.31,62.30,76.95,78.75,84.29,113.99,138.87,155.39,172.64 ;{ }^{11} \mathrm{~B}$ NMR $(128$ 
$\mathrm{MHz}$, Acetone- $\left.d_{6}\right) \delta 26.33$; HRMS (ESI+) $m / z$ calcd for $\left[\mathrm{C}_{23} \mathrm{H}_{39} \mathrm{O}_{6} \mathrm{~N}_{2} \mathrm{~B}+\mathrm{Na}\right]^{+} 473.2793$, found 473.2794.

tert-Butyl

((2S,3R)-3-hydroxy-1-oxo-1-(((R)-1-((3aS,4S,6S,7a R)-3a,5,5trimethylhexahydro-4,6-methanobenzo $[d][1,3,2]$ dioxaborol-2-yl)pent-4-en-1-

yl)amino)butan-2-yl)carbamate (22b). The product was synthesized following general coupling procedure C, using Boc-L-Thr as the amino acid and 20 as the amine. The crude product was purified by silica gel (eluent 60:40 EtOAc-hexanes) to give the product as a white solid (69\%). $R_{f}$ $=0.50$ (60:40 EtOAc-hexanes); $\mathrm{mp}=54-57^{\circ} \mathrm{C} ; \mathrm{IR}$ (film) $\mathrm{cm}^{-1} 3492,3349,3198,3079,2976,1720$, $1695,1607,1500,1391,1368,1238,1167,1078,1052,884 ;{ }^{1} \mathrm{H}$ NMR (500 MHz, Acetone- $\left.d_{6}\right) \delta$ $7.99(\mathrm{~s}, 1 \mathrm{H}), 5.94-5.72(\mathrm{~m}, 2 \mathrm{H}), 5.00(\mathrm{dq}, J=17.1,1.7 \mathrm{~Hz}, 1 \mathrm{H}), 4.91$ (ddd, $J=10.1,2.3,1.2 \mathrm{~Hz}$, $1 \mathrm{H}), 4.38(\mathrm{~d}, J=4.7 \mathrm{~Hz}, 1 \mathrm{H}), 4.24(\mathrm{dd}, J=8.8,2.2 \mathrm{~Hz}, 1 \mathrm{H}), 4.18(\mathrm{dq}, J=11.1,6.2,5.0 \mathrm{~Hz}, 1 \mathrm{H})$, $4.15-3.93(\mathrm{~m}, 1 \mathrm{H}), 2.82(\mathrm{td}, J=6.9,4.1 \mathrm{~Hz}, 1 \mathrm{H}), 2.31$ (ddt, $J=14.0,8.7,2.5 \mathrm{~Hz}, 1 \mathrm{H}), 2.25-$ $2.07(\mathrm{~m}, 3 \mathrm{H}), 2.00-1.91(\mathrm{~m}, 1 \mathrm{H}), 1.91-1.83(\mathrm{~m}, 1 \mathrm{H}), 1.79(\mathrm{ddd}, J=14.1,3.2,2.3 \mathrm{~Hz}, 1 \mathrm{H}), 1.75$ - $1.67(\mathrm{~m}, 1 \mathrm{H}), 1.66-1.48(\mathrm{~m}, 2 \mathrm{H}), 1.43(\mathrm{~s}, 9 \mathrm{H}), 1.35$ (s, 3H), 1.27 (s, 3H), $1.16(\mathrm{~d}, J=6.2 \mathrm{~Hz}$, $3 \mathrm{H}), 0.86(\mathrm{~s}, 3 \mathrm{H}) ;{ }^{13} \mathrm{C}$ NMR (126 MHz, Acetone- $\left.d_{6}\right) \delta$ 19.71, 24.38, 27.04, 27.59, 28.51 (3C), $31.44,32.18,35.24,36.85,38.79,39.85,40.66,52.79,59.24,67.95,77.72,79.66,85.00,114.87$, 139.72, 156.48, 173.95; ${ }^{11} \mathrm{~B}$ NMR (161 MHz, Acetone- $\left.d_{6}\right) \delta 26.18$; HRMS (ESI+) $m / z$ calcd for $\left[\mathrm{C}_{24} \mathrm{H}_{41} \mathrm{O}_{6} \mathrm{~N}_{2} \mathrm{~B}+\mathrm{H}\right]^{+}$465.3130, found 465.3140.

tert-Butyl

((2S,3S)-3-hydroxy-1-oxo-1-(((R)-1-((3aS,4S,6S,7aR)-3a,5,5trimethylhexahydro-4,6-methanobenzo $[d][1,3,2]$ dioxaborol-2-yl)pent-4-en-1-

yl)amino)butan-2-yl)carbamate (22c). The product was synthesized following general coupling procedure C, using Boc-L-allo-Thr as the amino acid and 20 as the amine. The crude product was purified by silica gel (eluent 60:40 EtOAc-hexanes) to give the product as a white solid (61\%). $R_{f}$ $=0.38\left(70: 30\right.$ hexanes-EtOAc); $\mathrm{mp}=49-52^{\circ} \mathrm{C} ; \mathrm{IR}($ film $) \mathrm{cm}^{-1} 3424,3310,3075,2976,1720,1697$, 1641, 1607, 1500, 1451, 1389, 1368, 1218, 1167, 1080, 1020, 908; ${ }^{1} \mathrm{H}$ NMR (500 MHz, Acetone$\left.d_{6}\right) \delta 7.87(\mathrm{~s}, 1 \mathrm{H}), 6.05(\mathrm{~d}, J=8.4 \mathrm{~Hz}, 1 \mathrm{H}), 5.82(\mathrm{ddt}, J=17.0,10.2,6.7 \mathrm{~Hz}, 1 \mathrm{H}), 5.00(\mathrm{dq}, J=$ 17.1, $1.8 \mathrm{~Hz}, 1 \mathrm{H}), 4.91$ (ddd, $J=10.2,2.2,1.2 \mathrm{~Hz}, 1 \mathrm{H}), 4.27-4.22$ (m, 2H), 4.08 (t, $J=7.1 \mathrm{~Hz}$, $1 \mathrm{H}), 4.00(\mathrm{~h}, J=6.3 \mathrm{~Hz}, 1 \mathrm{H}), 2.86-2.79$ (m, 1H), 2.31 (ddt, $J=14.0,8.7,2.4 \mathrm{~Hz}, 1 \mathrm{H}), 2.22$ $2.08(\mathrm{~m}, 3 \mathrm{H}), 1.94(\mathrm{t}, J=5.6 \mathrm{~Hz}, 1 \mathrm{H}), 1.85(\mathrm{tt}, J=5.7,2.9 \mathrm{~Hz}, 1 \mathrm{H}), 1.78(\mathrm{ddd}, J=14.3,3.3,2.2$ $\mathrm{Hz}, 1 \mathrm{H}), 1.74-1.65(\mathrm{~m}, 1 \mathrm{H}), 1.65-1.57(\mathrm{~m}, 1 \mathrm{H}), 1.42(\mathrm{~s}, 9 \mathrm{H}), 1.34$ (s, 3H), 1.27 (s, 3H), 1.19 
$(\mathrm{d}, J=6.3 \mathrm{~Hz}, 3 \mathrm{H}), 0.86(\mathrm{~s}, 3 \mathrm{H}) ;{ }^{13} \mathrm{C}$ NMR (126 MHz, Acetone- $\left.d_{6}\right) \delta 19.85,24.36,26.98,27.57$, 28.52 (3C), 29.29, 31.30, 32.11, 36.74, 38.80, 39.21, 40.63, 52.70, 59.42, 68.79, 77.89, 79.60, 85.24, 114.90, 139.70, 156.47, 173.34; ${ }^{11} \mathrm{~B}$ NMR (161 MHz, Acetone-d6) $\delta$ 27.43; HRMS (ESI+) $m / z$ calcd for $\left[\mathrm{C}_{24} \mathrm{H}_{41} \mathrm{O}_{6} \mathrm{~N}_{2} \mathrm{~B}+\mathrm{H}\right]^{+} 465.3130$, found 465.3142 .

tert-Butyl ((2R)-3-hydroxy-1-oxo-1-(((1R)-1-((3aS,4S,6S)-3a,5,5-trimethylhexahydro-4,6methanobenzo $[d][1,3,2]$ dioxaborol-2-yl)pent-4-en-1-yl)amino)propan-2-yl)carbamate (22d). The product was synthesized following general coupling procedure C, using Boc-D-Ser as the amino acid and 20 as the amine. The crude product was purified by silica gel (eluent 60:40 EtOAchexanes) to give the product as a white solid (57\%). $R_{f}=0.31$ (70:30 hexanes-EtOAc); $\mathrm{mp}=47-$ $51^{\circ} \mathrm{C}$; IR (film) $\mathrm{cm}^{-1} 3412,3302,3075,2929,1701,1657,1607,1452,1391,1368,1219,1167$, 1054, 910; ${ }^{1} \mathrm{H}$ NMR (500 MHz, Acetone- $\left.d_{6}\right) \delta 8.01-7.20(\mathrm{~m}, 1 \mathrm{H}), 6.05(\mathrm{~d}, J=7.2 \mathrm{~Hz}, 1 \mathrm{H}), 5.82$ (ddt, $J=16.9,10.2,6.7 \mathrm{~Hz}, 1 \mathrm{H}), 5.00$ (dq, $J=17.1,1.7 \mathrm{~Hz}, 1 \mathrm{H}), 4.91$ (ddt, $J=10.2,2.3,1.2 \mathrm{~Hz}$, $1 \mathrm{H}), 4.25$ (dd, $J=8.7,2.2 \mathrm{~Hz}, 1 \mathrm{H}), 4.22-4.19$ (m, 1H), 4.14 (s, 1H), 3.82 (dd, $J=11.3,4.8 \mathrm{~Hz}$, 1H), 3.73 (dd, $J=10.8,5.6 \mathrm{~Hz}, 1 \mathrm{H}), 2.86$ (ddt, $J=8.5,6.3,3.1 \mathrm{~Hz}, 1 \mathrm{H}), 2.31$ (ddt, $J=13.9,8.8$, $2.5 \mathrm{~Hz}, 1 \mathrm{H}), 2.21-2.08(\mathrm{~m}, 3 \mathrm{H}), 1.95(\mathrm{t}, J=5.6 \mathrm{~Hz}, 1 \mathrm{H}), 1.85(\mathrm{tt}, J=5.8,2.9 \mathrm{~Hz}, 1 \mathrm{H}), 1.81-$ $1.74(\mathrm{~m}, 1 \mathrm{H}), 1.69$ (ddt, $J=13.1,9.2,6.5 \mathrm{~Hz}, 1 \mathrm{H}), 1.66-1.57(\mathrm{~m}, 1 \mathrm{H}), 1.42(\mathrm{~s}, 10 \mathrm{H}), 1.34(\mathrm{~s}$, $3 \mathrm{H}), 1.27(\mathrm{~s}, 3 \mathrm{H}), 0.86(\mathrm{~s}, 3 \mathrm{H}) ;{ }^{13} \mathrm{C}$ NMR (126 MHz, Acetone-d6) $\delta 24.35,26.98,27.56,28.52$ (3C), 29.27, 31.38, 32.05, 36.71, 38.81, 39.34, 40.61, 52.68, 56.00, 63.23, 77.87, 79.63, 85.28, 114.89, 139.73, 156.29, 173.32; ${ }^{11} \mathrm{~B}$ NMR (161 MHz, Acetone-d6) $\delta$ 27.28; HRMS (ESI+) $m / z$ calcd for $\left[\mathrm{C}_{23} \mathrm{H}_{39} \mathrm{O}_{6} \mathrm{~N}_{2} \mathrm{~B}+\mathrm{H}\right]^{+} 451.2974$, found 451.2985

Benzyl (S)-(1-0xo-1-(pyrrolidin-1-yl)propan-2-yl)carbamate (23a). The product was synthesized following general coupling procedure B, using Z-L-Ala as the amino acid and pyrrolidine as the amine, to give a white solid (49\%). $R_{f}=0.49\left(50: 50\right.$ Hexanes-EtOAc); ${ }^{1} \mathrm{H}$ NMR $\left(500 \mathrm{MHz}\right.$, Acetone- $\left.d_{6}\right) \delta 7.44-7.27(\mathrm{~m}, 5 \mathrm{H}), 6.34(\mathrm{~d}, J=7.9 \mathrm{~Hz}, 1 \mathrm{H}), 5.08(\mathrm{~s}, 2 \mathrm{H}), 4.43$ (p, $J=$ $7.1 \mathrm{~Hz}, 1 \mathrm{H}), 3.65(\mathrm{dt}, J=9.9,6.7 \mathrm{~Hz}, 1 \mathrm{H}), 3.51(\mathrm{dt}, J=9.9,6.9 \mathrm{~Hz}, 1 \mathrm{H}), 3.42$ (dt, $J=11.8,7.1$ $\mathrm{Hz}, 1 \mathrm{H}), 3.33$ (dt, $J=11.7,6.8 \mathrm{~Hz}, 1 \mathrm{H}), 1.98$ (p, $J=6.8 \mathrm{~Hz}, 2 \mathrm{H}), 1.85$ (p, $J=6.9 \mathrm{~Hz}, 2 \mathrm{H}), 1.28$ $(\mathrm{d}, J=6.9 \mathrm{~Hz}, 3 \mathrm{H}) ;{ }^{13} \mathrm{C} \mathrm{NMR}\left(126 \mathrm{MHz}\right.$, Acetone- $\left.d_{6}\right) \delta 18.29,24.71,26.76,46.51,46.71,49.16$, 66.57, 128.61 (3C), 129.19 (2C), 138.31, 156.33, 171.19. Spectral and physical data were in accordance with the literature. ${ }^{60}$ 
benzyl ((S)-1-((S)-2-cyanopyrrolidin-1-yl)-1-oxopropan-2-yl)carbamate $\quad(23 b) . \quad$ The product was synthesized following general coupling procedure B, using Z-L-Ala as the amino acid and prolinonitrile PTSA salt as the amine, to give the product as a clear oil $(59 \%) . R_{f}=0.50(50: 50$ Hexanes-EtOAc); ${ }^{1} \mathrm{H}$ NMR (500 MHz, Chloroform- $d$ ) $\delta 7.39-7.28$ (m, 5H), 5.56 (d, $J=8.2 \mathrm{~Hz}$, $1 \mathrm{H}), 5.15-5.02(\mathrm{~m}, 2 \mathrm{H}), 4.82-4.72(\mathrm{~m}, 1 \mathrm{H}), 4.48(\mathrm{dt}, J=13.8,7.2 \mathrm{~Hz}, 1 \mathrm{H}), 3.74-3.59(\mathrm{~m}, 2 \mathrm{H})$, $2.36-2.08(\mathrm{~m}, 4 \mathrm{H}), 1.39(\mathrm{~d}, J=6.9 \mathrm{~Hz}, 3 \mathrm{H})$. Spectral and physical data were previously published by our group. ${ }^{19}$

\section{Benzyl ～( $\quad(S)-1-0 x 0-1-((R)-2-((3 a S, 4 S, 6 S, 7 a R)-3 a, 5,5-t r i m e t h y l h e x a h y d r o-4,6-$} methanobenzo $[d][1,3,2]$ dioxaborol-2-yl)pyrrolidin-1-yl)propan-2-yl)carbamate (23c). The product was synthesized following general coupling procedure $\mathrm{C}$, using Z-L-Ala as the amino acid and 26 as the amine, to give a white foam $(85 \%) . R_{f}=0.42\left(50: 50\right.$ Hexanes-EtOAc); IR (film) $\mathrm{cm}^{-}$ ${ }^{1}$ 3302, 3036, 2921, 1719, 1625, 1498, 1453, 1387, 1374, 1240, 1054, 1029, 741; ${ }^{1} \mathrm{H}$ NMR (500 $\mathrm{MHz}$, Acetone- $\left.d_{6}\right) \delta 8.08-7.10(\mathrm{~m}, 10 \mathrm{H}), 6.62-6.30(\mathrm{~m}, 1 \mathrm{H}), 6.29-5.90(\mathrm{~m}, 1 \mathrm{H}), 5.15-4.97$ $(\mathrm{m}, 4 \mathrm{H}), 4.51-4.35(\mathrm{~m}, 2 \mathrm{H}), 4.26(\mathrm{ddd}, J=8.9,7.2,2.3 \mathrm{~Hz}, 2 \mathrm{H}), 4.00-3.68(\mathrm{~m}, 1 \mathrm{H}), 3.66-3.28$ (m, 3H), $3.04(\mathrm{dd}, J=10.1,6.8 \mathrm{~Hz}, 1 \mathrm{H}), 2.96(\mathrm{dd}, J=9.8,7.0 \mathrm{~Hz}, 1 \mathrm{H}), 2.43-2.24$ (m, 2H), 2.11 (ddtt, $J=10.8,6.3,4.6,2.1 \mathrm{~Hz}, 4 \mathrm{H}), 2.03-1.91(\mathrm{~m}, 6 \mathrm{H}), 1.90-1.75(\mathrm{~m}, 4 \mathrm{H}), 1.74-1.65(\mathrm{~m}$, 2H), $1.64-1.45(\mathrm{~m}, 2 \mathrm{H}), 1.44-1.36(\mathrm{~m}, 2 \mathrm{H}), 1.35$ (s, 3H), 1.27 (d, J=5.0 Hz, 10H), $1.26-1.20$ $(\mathrm{m}, 3 \mathrm{H}), 0.85(\mathrm{~d}, J=5.3 \mathrm{~Hz}, 6 \mathrm{H}) ;{ }^{13} \mathrm{C} \mathrm{NMR}\left(126 \mathrm{MHz}\right.$, Acetone- $\left.d_{6}\right) \delta 17.99,18.37,24.27(2 \mathrm{C})$, 26.72, 26.79, 27.39, 27.46, 27.48, 27.80, 28.11, 28.18, 28.99, 29.06, 36.26, 36.34, 38.83, 38.87, 40.43 (2C), 45.41 (2C), 46.73, 46.79, 48.50, 48.68, 52.23, 52.38, 66.56, 66.58, 78.26, 78.26, 85.83, 85.98, 128.56 (2C), 128.58 (2C), 128.60 (2C), 129.17 (4C), 138.28 (2C), 156.20, 156.32, 171.04, 171.17; ${ }^{11} \mathrm{~B}$ NMR (161 MHz, Acetone- $d_{6}$ ) $\delta 31.39$; HRMS (ESI+) $m / z$ calcd for $\left[\mathrm{C}_{25} \mathrm{H}_{35} \mathrm{O}_{5} \mathrm{~N}_{2} \mathrm{~B}+\right.$ $\mathrm{H}]^{+}$455.2712, found 455.2711.

tert-Butyl ( $\quad((S)-1-0 x 0-1-((R)-2-((3 a S, 4 S, 6 S, 7 \mathrm{a} R)-3 \mathrm{a}, 5,5-t r i m e t h y l h e x a h y d r o-4,6-$ methanobenzo $[d][1,3,2]$ dioxaborol-2-yl)pyrrolidin-1-yl)propan-2-yl)carbamate (23d). The product was synthesized following general coupling procedure $\mathrm{C}$, using Boc-L-Ala as the amino acid and 26 as the amine, to give a white foam (64\%). $R_{f}=0.41$ (60:40 Hexanes-EtOAc); IR (film) $\mathrm{cm}^{-1} 3321,2924,1710,1627,1451,1389,1366,1242,1167,1054,1029 ;{ }^{1} \mathrm{H}$ NMR (500 MHz, Acetone- $\left.d_{6}\right) \delta 5.87(\mathrm{~d}, J=7.8 \mathrm{~Hz}, 1 \mathrm{H}), 5.78(\mathrm{~d}, J=8.2 \mathrm{~Hz}, 1 \mathrm{H}), 4.34(\mathrm{p}, J=7.0 \mathrm{~Hz}, 2 \mathrm{H}), 4.27$ $(\mathrm{ddd}, J=11.3,8.9,2.3 \mathrm{~Hz}, 2 \mathrm{H}), 3.73-3.67(\mathrm{~m}, 1 \mathrm{H}), 3.65-3.52(\mathrm{~m}, 2 \mathrm{H}), 3.49-3.39(\mathrm{~m}, 1 \mathrm{H})$, 
$3.03(\mathrm{dd}, J=10.1,6.7 \mathrm{~Hz}, 1 \mathrm{H}), 2.94(\mathrm{dd}, J=9.8,7.0 \mathrm{~Hz}, 1 \mathrm{H}), 2.42-2.25(\mathrm{~m}, 2 \mathrm{H}), 2.17-2.07$ (m, 4H), $2.03-1.91(\mathrm{~m}, 6 \mathrm{H}), 1.89-1.82(\mathrm{~m}, 2 \mathrm{H}), 1.82-1.76(\mathrm{~m}, 1 \mathrm{H}), 1.76-1.57$ (m, 3H), 1.52 - $1.44(\mathrm{~m}, 2 \mathrm{H}), 1.42-1.38(\mathrm{~m}, 18 \mathrm{H}), 1.35(\mathrm{~s}, 3 \mathrm{H}), 1.30$ (s, 3H), 1.27 (s, 6H), 1.25 (d, J=4.4 Hz, $3 \mathrm{H}), 1.22(\mathrm{~d}, J=4.2 \mathrm{~Hz}, 3 \mathrm{H}), 0.85(\mathrm{~s}, 6 \mathrm{H}) ;{ }^{13} \mathrm{C}$ NMR (126 MHz, Acetone- $\left.d_{6}\right) \delta 18.12,18.35,24.26$ (2C), 26.71, 26.78, 27.38, 27.46, 27.48, 27.77, 28.11, 28.19, 28.56 (3C), 28.59 (3C), 28.98, 29.12, 36.25, 36.38, 38.83, 38.86, 40.42, 40.45, 45.35 (2C), 46.67, 46.76, 47.96, 48.12, 52.23, 52.41, $78.21,78.23,79.00,79.01,85.80,85.97,155.70,155.72,171.33,171.56 ;{ }^{11} \mathrm{~B} \mathrm{NMR}(161 \mathrm{MHz}$, Acetone- $\left.d_{6}\right) \delta 31.17$; HRMS (ESI+) $m / z$ calcd for $\left[\mathrm{C}_{22} \mathrm{H}_{37} \mathrm{O}_{5} \mathrm{~N}_{2} \mathrm{~B}+\mathrm{H}\right]^{+} 421.2868$, found 421.2864 .

tert-Butyl $\quad((R)-1-0 x 0-1-((R)-2-((3 a S, 4 S, 6 S, 7 \mathrm{a} R)-3 \mathrm{a}, 5,5-t r i m e t h y l h e x a h y d r o-4,6-$ methanobenzo $[d][1,3,2]$ dioxaborol-2-yl)pyrrolidin-1-yl)propan-2-yl)carbamate (24a). The product was synthesized following general coupling procedure $\mathrm{C}$, using Boc-D-Ala as the amino acid and 26 as the amine, to give a mixture of diastereomers as a white foam $(40 \%) . R_{f}=0.39$ (60:40 Hexanes-EtOAc); IR (film) cm-1 3317, 2928, 1713, 1629, 1451, 1389, 1366, 1243, 1165 , 1031; ${ }^{1} \mathrm{H}$ NMR (500 MHz, Acetone-d6) $\delta 5.86(\mathrm{~d}, J=7.8 \mathrm{~Hz}, 1 \mathrm{H}), 5.77$ (d, $\left.J=7.8 \mathrm{~Hz}, 1 \mathrm{H}\right), 4.35$ $(\mathrm{td}, J=7.3,3.1 \mathrm{~Hz}, 2 \mathrm{H}), 4.29(\mathrm{dd}, J=8.9,2.3 \mathrm{~Hz}, 1 \mathrm{H}), 4.24(\mathrm{dd}, J=8.8,2.2 \mathrm{~Hz}, 1 \mathrm{H}), 3.76-3.67$ (m, 1H), $3.65-3.51(\mathrm{~m}, 2 \mathrm{H}), 3.44(\mathrm{td}, J=9.4,6.7 \mathrm{~Hz}, 1 \mathrm{H}), 3.03(\mathrm{dd}, J=10.3,6.8 \mathrm{~Hz}, 1 \mathrm{H}), 2.97$ $-2.89(\mathrm{~m}, 1 \mathrm{H}), 2.39-2.26(\mathrm{~m}, 2 \mathrm{H}), 2.20-2.07(\mathrm{~m}, 4 \mathrm{H}), 2.03-1.90(\mathrm{~m}, 6 \mathrm{H}), 1.85(\mathrm{tq}, J=5.8$, $2.9 \mathrm{~Hz}, 2 \mathrm{H}), 1.82-1.64(\mathrm{~m}, 4 \mathrm{H}), 1.43-1.41(\mathrm{~m}, 10 \mathrm{H}), 1.41-1.39(\mathrm{~m}, 10 \mathrm{H}), 1.36(\mathrm{~s}, 3 \mathrm{H}), 1.30$ $(\mathrm{s}, 3 \mathrm{H}), 1.28(\mathrm{~s}, 3 \mathrm{H}), 1.27(\mathrm{~s}, 3 \mathrm{H}), 1.26-1.23(\mathrm{~m}, 3 \mathrm{H}), 1.22(\mathrm{~s}, 3 \mathrm{H}), 0.85(\mathrm{~s}, 3 \mathrm{H}), 0.85(\mathrm{~s}, 3 \mathrm{H})$; ${ }^{13} \mathrm{C}$ NMR $\left(126 \mathrm{MHz}\right.$, Acetone- $\left.d_{6}\right) \delta 18.25,18.60,24.26,24.28,26.80$ (2C), 27.46, 27.49, 27.55, 27.70, 28.18 (2C), 28.58 (3C), 28.59 (3C), 28.94, 29.06, 36.35 (2C), 38.85 (2C), 40.40, 40.44, 45.38 (2C), 46.65, 46.83, 47.99, 48.16, 52.33, 52.37, 78.05, 78.33, 78.96, 79.06, 85.84, 86.00, 155.54, 155.68, 171.18, 171.43; ${ }^{11} \mathrm{~B}$ NMR (161 MHz, Acetone- $\left.d_{6}\right) \delta 31.25 ; \mathrm{HRMS}(\mathrm{ESI}+) \mathrm{m} / z$ calcd for $\left[\mathrm{C}_{22} \mathrm{H}_{37} \mathrm{O}_{5} \mathrm{~N}_{2} \mathrm{~B}+\mathrm{H}\right]^{+} 421.2868$, found 421.2869 .

\section{Benzyl ((2S)-3-methyl-1-oxo-1-(2-((3aS,4S,6S,7aR)-3a,5,5-trimethylhexahydro-4,6-} methanobenzo $[d][1,3,2]$ dioxaborol-2-yl)pyrrolidin-1-yl)butan-2-yl)carbamate (25a). The product was synthesized following general coupling procedure $\mathrm{C}$, using $\mathrm{Z}-\mathrm{L}-\mathrm{V}$ al as the amino acid and 26 as the amine, to give a white foam $(60 \%) . R_{f}=0.31\left(65: 45\right.$ Hexanes-EtOAc); IR (film) $\mathrm{cm}^{-}$ ${ }^{1} 3250,3067,2968,1715,1619,1502,1451,1389,1376,1368,1217,1078,1028 ;{ }^{1} \mathrm{H}$ NMR (500 $\mathrm{MHz}$, Acetone- $\left.d_{6}\right) \delta 7.91-6.90(\mathrm{~m}, 10 \mathrm{H}), 6.26(\mathrm{~d}, J=9.0 \mathrm{~Hz}, 1 \mathrm{H}), 6.15(\mathrm{~d}, J=9.2 \mathrm{~Hz}, 1 \mathrm{H}), 5.18$ 
- $4.96(\mathrm{~m}, 4 \mathrm{H}), 4.44-4.12(\mathrm{~m}, 4 \mathrm{H}), 4.01-3.78(\mathrm{~m}, 1 \mathrm{H}), 3.73-3.40(\mathrm{~m}, 3 \mathrm{H}), 3.32$ - $2.93(\mathrm{~m}$, 2H), $2.41-2.20(\mathrm{~m}, 2 \mathrm{H}), 2.15-2.07(\mathrm{~m}, 3 \mathrm{H}), 2.03-1.90(\mathrm{~m}, 6 \mathrm{H}), 1.90-1.66(\mathrm{~m}, 6 \mathrm{H}), 1.63-$ $1.45(\mathrm{~m}, 2 \mathrm{H}), 1.35-1.33(\mathrm{~m}, 3 \mathrm{H}), 1.27(\mathrm{~s}, 12 \mathrm{H}), 1.00-0.92(\mathrm{~m}, 12 \mathrm{H}), 0.86-0.82(\mathrm{~m}, 6 \mathrm{H}) ;{ }^{13} \mathrm{C}$ NMR (126 MHz, Acetone-d6) $\delta 18.30$ (2C), 19.42, 19.66, 24.28 (2C), 26.82 (2C), 27.30, 27.47, 27.50, 27.92, 28.17 (2C), 29.05, 29.09, 31.58, 31.60, 36.24, 36.42, 38.82, 38.86, 40.41, 40.47, 45.28 (2C), 47.03, 47.20, 52.22, 52.42, 58.12, 58.30, 66.63, 66.69, 78.20, 78.26, 85.67, 86.08, 128.42 (2C), 128.56 (4C), 129.17 (4C), 138.29, 138.35, 157.07, 157.10, 170.48, 170.79; ${ }^{11} \mathrm{~B}$ NMR $\left(161 \mathrm{MHz}\right.$, Acetone- $\left.d_{6}\right) \delta 30.84$; HRMS (ESI+) $m / z$ calcd for $\left[\mathrm{C}_{27} \mathrm{H}_{39} \mathrm{O}_{5} \mathrm{~N}_{2} \mathrm{~B}+\mathrm{H}\right]^{+} 483.3025$, found 483.3027 .

tert-Butyl ((S)-3-methyl-1-0xo-1-((R)-2-((3a $S, 4 S, 6 S, 7 \mathrm{a} R)-3 \mathrm{a}, 5,5-t r i m e t h y l h e x a h y d r o-4,6-$ methanobenzo $[d][1,3,2]$ dioxaborol-2-yl)pyrrolidin-1-yl)butan-2-yl)carbamate $(25 b)$. The product was synthesized following general coupling procedure $\mathrm{C}$, using Boc-L-Val as the amino acid and 26 as the amine, to give a white foam (65\%). $R_{f}=0.36$ (70:30 Hexanes-EtOAc; IR (film) $\mathrm{cm}^{-1} 3321,2968,1715,1619,1449,1389,1366,1169,1076,1032 ;{ }^{1} \mathrm{H}$ NMR (500 MHz, Acetone$\left.d_{6}\right) \delta 5.72(\mathrm{~d}, J=8.8 \mathrm{~Hz}, 1 \mathrm{H}), 5.64(\mathrm{~d}, J=9.2 \mathrm{~Hz}, 1 \mathrm{H}), 4.32-4.22(\mathrm{~m}, 2 \mathrm{H}), 4.20-3.91(\mathrm{~m}, 2 \mathrm{H})$, 3.77 (ddd, $J=10.6,8.5,2.8 \mathrm{~Hz}, 1 \mathrm{H}), 3.67$ (dt, $J=10.0,7.6 \mathrm{~Hz}, 1 \mathrm{H}), 3.59$ (ddd, $J=10.2,8.1,4.2$ $\mathrm{Hz}, 1 \mathrm{H}), 3.48$ (td, $J=9.7,6.8 \mathrm{~Hz}, 1 \mathrm{H}), 3.01$ (dd, $J=10.7,6.8 \mathrm{~Hz}, 1 \mathrm{H}), 2.96$ (dd, $J=9.5,7.1 \mathrm{~Hz}$, $1 \mathrm{H}), 2.38-2.26(\mathrm{~m}, 2 \mathrm{H}), 2.18-2.07(\mathrm{~m}, 4 \mathrm{H}), 2.03-1.90(\mathrm{~m}, 8 \mathrm{H}), 1.88-1.82(\mathrm{~m}, 2 \mathrm{H}), 1.82-$ $1.58(\mathrm{~m}, 4 \mathrm{H}), 1.48(\mathrm{dd}, J=15.0,10.7 \mathrm{~Hz}, 2 \mathrm{H}), 1.40(\mathrm{~s}, 18 \mathrm{H}), 1.34(\mathrm{~s}, 3 \mathrm{H}), 1.30(\mathrm{~s}, 3 \mathrm{H}), 1.27$ (s, $3 \mathrm{H}), 1.27(\mathrm{~s}, 3 \mathrm{H}), 0.97-0.92(\mathrm{~m}, 6 \mathrm{H}), 0.92-0.88(\mathrm{~m}, 6 \mathrm{H}), 0.85(\mathrm{~s}, 6 \mathrm{H}) .{ }^{13} \mathrm{C} \mathrm{NMR}(126 \mathrm{MHz}$, Acetone- $\left.d_{6}\right) \delta 17.14,17.32,18.66,18.84,23.41(2 \mathrm{C}), 25.93,25.95,26.42(2 \mathrm{C}), 26.60,26.63,27.02$ (2C), 27.31 (2C), 27.68 (3C), 27.72 (3C), 28.18, 28.29, 30.71, 30.80, 35.38, 35.62, 37.96, 37.99, 39.54, 39.62, $44.36(2 \mathrm{C}), 46.08,46.24,51.36,51.62,56.54,56.61,77.28,77.38,84.77,85.19$, 155.56, 155.62, 169.76, 170.19; ${ }^{11} \mathrm{~B}$ NMR (161 MHz, Acetone- $\left.d_{6}\right) \delta 30.70$; HRMS (ESI+) $m / z$ calcd for $\left[\mathrm{C}_{22} \mathrm{H}_{41} \mathrm{O}_{5} \mathrm{~N}_{2} \mathrm{~B}+\mathrm{H}\right]^{+} 449.3181$, found 449.3180 .

General acid-catalyzed oxidative cyclization procedure A. The dipeptide (1 eq) was diluted in anhydrous DCM (0.02 M), and 2-3 drops of Sudan III solution (1mg/mL in DCM) were added (enough to reach a pink color). The solution was cooled to $-78^{\circ} \mathrm{C}$, and $\mathrm{N}_{2}$ gas was bubbled into the solution for 5 minutes, followed by ozone ( $\sim 80 \%$ ozone output). When the solution turned dark blue, ozone addition was stopped, and $\mathrm{N}_{2}$ was bubbled until the solution was colorless. Polymer- 
bound triphenylphospine (1.5 eq, $\sim 3 \mathrm{mmol} / \mathrm{g}$ loading, CAS 39319-11-4) was added, and the mixture stirred for 5 minutes at $-78^{\circ} \mathrm{C}$, then at room temperature overnight under argon atmosphere, after which the mixture became slightly opaque. TFA (1.5 eq) was added at room temperature, and the mixture was stirred for $2 \mathrm{~h}$. The mixture was filtered through Celite ${ }^{\circledR}$. The solid was rinsed with DCM, and the filtrate was concentrated in vacuo. The residue was redissolved in EtOAc and washed with saturated $\mathrm{NH}_{4} \mathrm{Cl}$ and brine. The organic layer was dried over $\mathrm{Na}_{2} \mathrm{SO}_{4}$, filtered, and concentrated in vacuo to give the crude product, which was purified by flash chromatography on a silica gel column to give the pure product.

General acid-catalyzed oxidative cyclization procedure B. The dipeptide (1 eq) was diluted in anhydrous DCM $(0.02 \mathrm{M})$ and cooled to $-78^{\circ} \mathrm{C}$. $\mathrm{N}_{2}$ gas was bubbled into the solution for 5 minutes, followed by ozone ( $\sim 80 \%$ output). When the solution turned a deep blue, ozone addition was immediately stopped, and $\mathrm{N}_{2}$ was bubbled until the solution was colorless. Polymer-bound triphenylphospine (1.5 eq, $\sim 3 \mathrm{mmol} / \mathrm{g}$ loading, CAS 39319-11-4) was added, and the mixture stirred for 5 minutes at $-78^{\circ} \mathrm{C}$, then at room temperature overnight, after which the mixture became slightly opaque. TFA (1.5 eq) was added at room temperature, and the mixture was stirred for $2 \mathrm{~h}$. The mixture was filtered through Celite ${ }^{\circledR}$. The solid was rinsed with DCM, and the filtrate was concentrated in vacuo. The residue was redissolved in EtOAc and washed with saturated $\mathrm{NH}_{4} \mathrm{Cl}$ and brine. The organic layer was dried over $\mathrm{Na}_{2} \mathrm{SO}_{4}$, filtered, and concentrated in vacuo to give the crude product, which was purified by flash chromatography on a silica gel column to give the pure product.

\section{Benzyl}

((3S,6S,8aS)-6-cyano-4-oxohexahydro-2H-pyrrolo[2,1-b][1,3]oxazin-3-

yl)carbamate (10a). The product was synthesized according to general acid-catalyzed oxidative cyclization procedure B from peptide $\mathbf{1 8}$ and purified by flash chromatography on a silica gel column (eluent 80-20 EtOAc-hexanes) to give the product as a white solid (33\%). $R_{f}=0.56(100 \%$ EtOAc); $\mathrm{mp}=167-170^{\circ} \mathrm{C}$; IR (film) $\mathrm{cm}^{-1} 3361,3031,2952,1719,1685,1532,1433,1257,1064$, 1064, 1018, 698; ${ }^{1} \mathrm{H}$ NMR (500 MHz, Acetone- $\left.d_{6}\right) \delta 7.59-7.23(\mathrm{~m}, 5 \mathrm{H}), 6.71(\mathrm{~d}, J=8.4 \mathrm{~Hz}, 1 \mathrm{H})$, $5.41(\mathrm{t}, J=6.5 \mathrm{~Hz}, 1 \mathrm{H}), 5.12(\mathrm{~s}, 2 \mathrm{H}), 4.69(\mathrm{dd}, J=5.3,3.5 \mathrm{~Hz}, 1 \mathrm{H}), 4.62(\mathrm{q}, J=8.6 \mathrm{~Hz}, 1 \mathrm{H}), 4.38$ $(\mathrm{t}, J=9.6 \mathrm{~Hz}, 1 \mathrm{H}), 3.78(\mathrm{t}, J=8.5 \mathrm{~Hz}, 1 \mathrm{H}), 2.52$ (ddt, $J=13.2,5.6,3.3 \mathrm{~Hz}, 1 \mathrm{H}), 2.33(\mathrm{dq}, J=9.9$, $3.0 \mathrm{~Hz}, 2 \mathrm{H}), 2.08-1.97(\mathrm{~m}, 1 \mathrm{H}) ;{ }^{13} \mathrm{C} \mathrm{NMR}\left(126 \mathrm{MHz}\right.$, Acetone- $\left.d_{6}\right) \delta 28.41,32.01,45.59,50.42$, 
67.02, 68.85, 88.52, 118.79, 128.64 (2C), 128.69, 129.22 (2C), 138.03, 157.29, 167.37; HRMS $(\mathrm{ESI}+) \mathrm{m} / z$ calcd for $\left[\mathrm{C}_{16} \mathrm{H}_{17} \mathrm{O}_{4} \mathrm{~N}_{3}+\mathrm{Na}\right]^{+} 338.1111$, found 338.1102 .

Benzyl ((3S,8aS)-4-oxohexahydro-2H-pyrrolo[2,1-b][1,3]oxazin-3-yl)carbamate (10b) The product was synthesized according to general acid-catalyzed oxidative cyclization procedure A from peptide 14 and purified by flash chromatography on a silica gel column (eluent 80-20 EtOAchexanes) to give the product as a white solid $(40 \%) . R_{f}=0.39\left(100 \%\right.$ EtOAc); $\mathrm{mp}=118-122^{\circ} \mathrm{C}$; IR (film) $\mathrm{cm}^{-1} 3305,3063,2980,1717,1669,1530,1443,1217,1064,1018,695 ;{ }^{1} \mathrm{H}$ NMR (500 MHz, Acetone- $\left.d_{6}\right) \delta 7.48-7.25(\mathrm{~m}, 5 \mathrm{H}), 6.50(\mathrm{~s}, 1 \mathrm{H}), 5.20(\mathrm{t}, J=5.3 \mathrm{~Hz}, 1 \mathrm{H}), 5.10(\mathrm{~s}, 2 \mathrm{H}), 4.44$ (q, $J=7.4 \mathrm{~Hz}, 1 \mathrm{H}), 4.28(\mathrm{dd}, J=10.2,8.1 \mathrm{~Hz}, 1 \mathrm{H}), 3.76-3.66$ (m, 2H), 3.26 (ddd, $J=11.9,7.3$, $5.1 \mathrm{~Hz}, 1 \mathrm{H}), 2.23(\mathrm{td}, J=10.4,10.0,4.9 \mathrm{~Hz}, 1 \mathrm{H}), 1.96-1.87(\mathrm{~m}, 1 \mathrm{H}), 1.87-1.76(\mathrm{~m}, 2 \mathrm{H}) ;{ }^{13} \mathrm{C}$ NMR $\left(126 \mathrm{MHz}\right.$, Acetone- $\left.d_{6}\right) \delta$ 21.89, 33.03, 45.26, 50.22, 66.92, 68.81, 88.01, 128.65 (3C), 129.19 (2C), 138.06, 157.14, 166.64; HRMS (ESI+) $m / z$ calcd for $\left[\mathrm{C}_{15} \mathrm{H}_{18} \mathrm{O}_{4} \mathrm{~N}_{2}+\mathrm{Na}\right]^{+} 313.1159$, found 313.1163 .

\section{Benzyl ((3S,6R,8aS)-4-oxo-6-((3aS,4S,6S,7aR)-3a,5,5-trimethylhexahydro-4,6-} methanobenzo $[d][1,3,2]$ dioxaborol-2-yl)hexahydro-2H-pyrrolo[2,1-b][1,3]oxazin-3-

yl)carbamate (10c). The product was synthesized according to general acid-catalyzed oxidative cyclization procedure B from peptide 21a and purified by flash chromatography on a silica gel column (eluent 50:50 hexanes-EtOAc) to give the product as a white foam (58\%). $R_{f}=0.47$ (50:50 hexanes-EtOAc); IR (film) cm $\mathrm{cm}^{-1}$ 3325, 3067, 2921, 1720, 1673, 1586, 1451, 1391, 1376, 1219, 1029; ${ }^{1} \mathrm{H}$ NMR $\left(500 \mathrm{MHz}\right.$, Acetone- $\left.d_{6}\right) \delta 7.44-7.26(\mathrm{~m}, 5 \mathrm{H}), 6.25(\mathrm{~d}, J=6.9 \mathrm{~Hz}, 1 \mathrm{H}), 5.20(\mathrm{dd}$, $J=6.1,4.0 \mathrm{~Hz}, 1 \mathrm{H}), 5.11(\mathrm{~s}, 2 \mathrm{H}), 4.41(\mathrm{q}, J=6.6 \mathrm{~Hz}, 1 \mathrm{H}), 4.29$ (dd, $J=8.8,2.1 \mathrm{~Hz}, 1 \mathrm{H}), 4.24$ (dd, $J=10.4,7.4 \mathrm{~Hz}, 1 \mathrm{H}), 3.72$ (dd, $J=10.5,6.2 \mathrm{~Hz}, 1 \mathrm{H}), 3.05$ (t, $J=7.3 \mathrm{~Hz}, 1 \mathrm{H}), 2.33$ (ddt, $J=$ 14.1, 8.9, $2.5 \mathrm{~Hz}, 1 \mathrm{H}), 2.26-2.18(\mathrm{~m}, 1 \mathrm{H}), 2.14$ (ddt, $J=10.2,7.7,3.9 \mathrm{~Hz}, 1 \mathrm{H}), 2.01-1.93(\mathrm{~m}$, 3H), $1.91-1.83$ (m, 2H), 1.78 (ddd, $J=14.4,3.3,2.2 \mathrm{~Hz}, 1 \mathrm{H}), 1.39$ (s, 3H), $1.34-1.29(\mathrm{~m}, 1 \mathrm{H})$, $1.28-1.19(\mathrm{~m}, 3 \mathrm{H}), 0.85$ (s, 3H); ${ }^{13} \mathrm{C}$ NMR $\left(126 \mathrm{MHz}\right.$, Acetone- $\left.d_{6}\right) \delta$ 24.25, 24.96, 26.82, 27.43, $28.75,33.71,36.17,38.86,40.38,43.46,50.00,52.21,66.97,68.80,78.36,86.48,88.29,128.66$ (3C), 129.20 (2C), 138.04, 157.03, 166.39; ${ }^{11} \mathrm{~B}$ NMR (161 MHz, Acetone- $\left.d_{6}\right) \delta 31.58$; HRMS $(\mathrm{ESI}+) \mathrm{m} / z$ calcd for $\left[\mathrm{C}_{25} \mathrm{H}_{33} \mathrm{O}_{6} \mathrm{~N}_{2} \mathrm{~B}+\mathrm{Na}\right]^{+} 491.2324$, found 491.2331 .

tert-Butyl

((3S,6R,8aS)-4-oxo-6-((3aS,4S,6S,7aR)-3a,5,5-trimethylhexahydro-4,6methanobenzo[d][1,3,2]dioxaborol-2-yl)hexahydro-2H-pyrrolo[2,1-b][1,3] oxazin-3- 
yl)carbamate (10e). The product was synthesized according to general acid-catalyzed oxidative cyclization procedure B from peptide 22a and purified by flash chromatography on a silica gel column (eluent 60:40 hexanes-EtOAc) to give the product as a white solid (52\%). $R_{f}=0.39$ (60:40 hexanes-EtOAc); $\mathrm{mp}=144-147^{\circ} \mathrm{C}$; IR (film) $\mathrm{cm}^{-1} 3337,2924,1715,1673,1449,1391,1368$, 1165, 1078, 1030; ${ }^{1} \mathrm{H}$ NMR $\left(500 \mathrm{MHz}\right.$, Acetone- $\left.d_{6}\right) \delta 5.75(\mathrm{~d}, J=6.6 \mathrm{~Hz}, 1 \mathrm{H}), 5.18(\mathrm{t}, J=5.1 \mathrm{~Hz}$, 1H), $4.34-4.26$ (m, 2H), 4.20 (dd, $J=10.3,7.2 \mathrm{~Hz}, 1 \mathrm{H}$ ), 3.67 (dd, $J=10.3,6.2 \mathrm{~Hz}, 1 \mathrm{H}), 3.06$ (t, $J=7.2 \mathrm{~Hz}, 1 \mathrm{H}), 2.35$ (ddt, $J=14.1,8.8,2.5 \mathrm{~Hz}, 1 \mathrm{H}), 2.26-2.18(\mathrm{~m}, 1 \mathrm{H}), 2.18-2.13(\mathrm{~m}, 1 \mathrm{H})$, $2.02-1.92(\mathrm{~m}, 3 \mathrm{H}), 1.92-1.85(\mathrm{~m}, 2 \mathrm{H}), 1.79(\mathrm{ddd}, J=14.4,3.3,2.2 \mathrm{~Hz}, 1 \mathrm{H}), 1.43(\mathrm{~s}, 9 \mathrm{H}), 1.40$ (s, 3H), $1.34-1.31(\mathrm{~m}, 1 \mathrm{H}), 1.29$ (s, 3H), 0.87 (s, 3H); ${ }^{13} \mathrm{C}$ NMR (126 MHz, Acetone- $\left.d_{6}\right) \delta 24.25$, 24.95, 26.82, 27.45, 28.49 (3C), 28.76, 33.73, 36.18, 38.88, 40.39, 43.62, 49.63, 52.21, 69.00, $78.39,79.61,86.48,88.20,156.28,166.63 ;{ }^{11} \mathrm{~B}$ NMR (161 MHz, Acetone- $\left.d_{6}\right) \delta 31.59$; HRMS (ESI+) $m / z$ calcd for $\left[\mathrm{C}_{22} \mathrm{H}_{35} \mathrm{O}_{6} \mathrm{~N}_{2} \mathrm{~B}+\mathrm{H}\right]^{+} 435.2661$, found 435.2667 .

tert-Butyl $\quad((3 R, 6 R, 8 \mathrm{a} R)-4-0 x 0-6-((3 \mathrm{a} S, 4 S, 6 S, 7 \mathrm{a} R)-3 \mathrm{a}, 5,5-$ trimethylhexahydro-4,6methanobenzo $[d][1,3,2]$ dioxaborol-2-yl)hexahydro-2 $H$-pyrrolo[2,1-b][1,3]oxazin-3-

yl)carbamate (11a). The product was synthesized according to general acid-catalyzed oxidative cyclization procedure B from peptide $22 \mathrm{~d}$ and purified by flash chromatography on a silica gel column (eluent 70:30 hexanes-EtOAc) to give the product as a white foam $(53 \%) . R_{f}=0.31$ (70:30 hexanes-EtOAc); IR (film) cm-1 3349, 2925, 1709, 1671, 1449, 1389, 1378, 1370, 1215, 1163 , 1076; ${ }^{1} \mathrm{H}$ NMR (500 MHz, Acetone- $\left.d_{6}\right) \delta 6.02(\mathrm{~d}, J=6.5 \mathrm{~Hz}, 1 \mathrm{H}), 5.22(\mathrm{t}, J=6.1 \mathrm{~Hz}, 1 \mathrm{H}), 4.33$ $(\mathrm{dt}, J=8.8,1.6 \mathrm{~Hz}, 2 \mathrm{H}), 4.26(\mathrm{dd}, J=11.5,7.2 \mathrm{~Hz}, 1 \mathrm{H}), 3.67(\mathrm{dd}, J=10.3,6.1 \mathrm{~Hz}, 1 \mathrm{H}), 3.36(\mathrm{dd}$, $J=10.3,6.9 \mathrm{~Hz}, 1 \mathrm{H}), 2.41-2.27(\mathrm{~m}, 2 \mathrm{H}), 2.21-2.11(\mathrm{~m}, 1 \mathrm{H}), 2.09(\mathrm{td}, J=6.1,5.4,2.8 \mathrm{~Hz}, 1 \mathrm{H})$, $1.98(\mathrm{t}, J=5.7 \mathrm{~Hz}, 1 \mathrm{H}), 1.95-1.81(\mathrm{~m}, 2 \mathrm{H}), 1.83-1.76(\mathrm{~m}, 2 \mathrm{H}), 1.78-1.69(\mathrm{~m}, 1 \mathrm{H}), 1.42(\mathrm{~s}$, 9H), $1.36(\mathrm{~s}, 3 \mathrm{H}), 1.28(\mathrm{~s}, 3 \mathrm{H}), 0.86(\mathrm{~s}, 3 \mathrm{H}) ;{ }^{13} \mathrm{C}$ NMR (126 MHz, Acetone- $\left.d_{6}\right) \delta 166.41,156.43$, $88.87,86.78,79.50,78.62,69.94,52.08,49.77,43.44,40.26,38.86,36.09,34.28,28.93,28.50$ (3C), 27.38, 26.83, 25.11, 24.19; ${ }^{11}$ B NMR (161 MHz, Acetone- $\left.d_{6}\right) \delta 31.87$; HRMS (ESI+) $m / z$ calcd for $\left[\mathrm{C}_{22} \mathrm{H}_{35} \mathrm{O}_{6} \mathrm{~N}_{2} \mathrm{~B}+\mathrm{Na}\right]^{+} 457.2480$, found 457.2468 .

\section{Benzyl ((2R,3S,6R,8aS)-2-methyl-4-oxo-6-((3a $S, 4 S, 6 S, 7 \mathrm{a} R)-3 \mathrm{a}, 5,5-$ trimethylhexahydro-} 4,6-methanobenzo $[d][1,3,2]$ dioxaborol-2-yl)hexahydro-2 $H$-pyrrolo[2,1-b][1,3]oxazin-3-

yl)carbamate (12a). The product was synthesized according to general acid-catalyzed oxidative cyclization procedure $\mathrm{B}$ from peptide $21 \mathrm{~b}$ and purified by flash chromatography on a silica gel 
column (eluent 50:50 hexanes-EtOAc) to give the product as a clear oil (59\%). $R_{f}=0.58(50: 50$ hexanes-EtOAc); IR (film) cm ${ }^{-1} 3409,1720,1675,1504,1454,1391,1376,1217,1056,1028 ;{ }^{1} \mathrm{H}$ NMR (500 MHz, Acetone- $\left.d_{6}\right) \delta 7.46-7.30(\mathrm{~m}, 5 \mathrm{H}), 6.06(\mathrm{~d}, J=8.0 \mathrm{~Hz}, 1 \mathrm{H}), 5.23(\mathrm{t}, J=5.1 \mathrm{~Hz}$, 1H), 5.12 (s, 2H), 4.43 (dd, $J=7.9,5.5 \mathrm{~Hz}, 1 \mathrm{H}), 4.34$ (p, $J=6.2 \mathrm{~Hz}, 1 \mathrm{H}), 4.29$ (dd, $J=8.9,2.2$ $\mathrm{Hz}, 1 \mathrm{H}$ ), 3.08 (dd, $J=8.2,6.0 \mathrm{~Hz}, 1 \mathrm{H}), 2.32$ (ddt, $J=14.1,8.9,2.5 \mathrm{~Hz}, 1 \mathrm{H}), 2.25-2.15$ (m, $1 \mathrm{H}$ ), $2.11(\mathrm{dtd}, J=10.9,6.4,2.3 \mathrm{~Hz}, 1 \mathrm{H}), 2.02-1.83(\mathrm{~m}, 5 \mathrm{H}), 1.78$ (ddd, $J=14.4,3.3,2.2 \mathrm{~Hz}, 1 \mathrm{H})$, $1.37(\mathrm{~s}, 3 \mathrm{H}), 1.36-1.31(\mathrm{~m}, 1 \mathrm{H}), 1.24(\mathrm{~s}, 3 \mathrm{H}), 1.12(\mathrm{~d}, J=6.3 \mathrm{~Hz}, 3 \mathrm{H}), 0.85(\mathrm{~s}, 3 \mathrm{H}) ;{ }^{13} \mathrm{C} \mathrm{NMR}$ $\left(126 \mathrm{MHz}\right.$, Acetone- $\left.d_{6}\right) \delta 17.05,24.26,24.57,26.80,27.43,28.80,33.52,36.15,38.87,40.39$, 43.07, 52.18, 53.55, 67.00, 73.39, 78.46, 86.50, 87.46, 128.59 (2C), 128.67, 129.22 (2C), 138.12, 157.11, 166.11; ${ }^{11} \mathrm{~B}$ NMR (161 MHz, Acetone- $\left.d_{6}\right) \delta 31.95$; HRMS (ESI+) $\mathrm{m} / \mathrm{z}$ calcd for $\left[\mathrm{C}_{26} \mathrm{H}_{35} \mathrm{O}_{6} \mathrm{~N}_{2} \mathrm{~B}+\mathrm{Na}\right]^{+}$505.2480, found 505.2489.

tert-Butyl

$((2 R, 3 S, 6 R, 8 \mathrm{a} S)-2-m e t h y l-4-0 x 0-6-((3 \mathrm{a} S, 4 S, 6 S, 7 \mathrm{a} R)-3 \mathrm{a}, 5,5-$

trimethylhexahydro-4,6-methanobenzo $[d][1,3,2]$ dioxaborol-2-yl)hexahydro- $2 H$ -

pyrrolo[2,1-b][1,3]oxazin-3-yl)carbamate (12b). The product was synthesized according to general acid-catalyzed oxidative cyclization procedure B from peptide $\mathbf{2 2 b}$ and purified by flash chromatography on a silica gel column (eluent 60:40 hexanes-EtOAc) to give the product as a white solid (56\%). $R_{f}=0.34\left(60: 40\right.$ hexanes-EtOAc); $\mathrm{mp}=131-134^{\circ} \mathrm{C}$; IR (film) $\mathrm{cm}^{-1} 3333,1717$, 1675, 1453, 1391, 1368, 1165, 1058, 1030; ${ }^{1} \mathrm{H}$ NMR (400 MHz, Acetone- $\left.d_{6}\right) \delta 5.57$ (d, J=7.0 Hz, $1 \mathrm{H}), 5.23(\mathrm{dd}, J=5.5,4.4 \mathrm{~Hz}, 1 \mathrm{H}), 4.39-4.26(\mathrm{~m}, 3 \mathrm{H}), 3.09(\mathrm{dd}, J=8.3,5.7 \mathrm{~Hz}, 1 \mathrm{H}), 2.35$ (ddt, $J=14.0,8.8,2.5 \mathrm{~Hz}, 1 \mathrm{H}), 2.26-2.11(\mathrm{~m}, 2 \mathrm{H}), 2.03-1.96(\mathrm{~m}, 2 \mathrm{H}), 1.95-1.89(\mathrm{~m}, 2 \mathrm{H}), 1.89-$ $1.84(\mathrm{~m}, 1 \mathrm{H}), 1.80$ (ddd, $J=14.3,3.3,2.2 \mathrm{~Hz}, 1 \mathrm{H}), 1.44$ (s, 9H), 1.39 (s, 3H), 1.37 - 1.32 (m, 1H), $1.29(\mathrm{~s}, 3 \mathrm{H}), 1.09(\mathrm{~d}, J=6.1 \mathrm{~Hz}, 3 \mathrm{H}), 0.87(\mathrm{~s}, 3 \mathrm{H}) ;{ }^{13} \mathrm{C}$ NMR (101 MHz, Acetone-d6) $\delta 165.37$, 155.28, 86.26, 85.53, 78.50, 77.54, 72.36, 52.06, 51.18, 42.17, 39.41, 37.92, 35.15, 32.59, 27.83, 27.51 (3C), 26.48, 25.80, 23.66, 23.26, 16.02; ${ }^{11}$ B peak reported for major rotamer; full spectrum provided as Supporting Information. ${ }^{11} \mathrm{~B}$ NMR (161 MHz, Acetone- $\left.d_{6}\right) \delta 31.80$; HRMS (ESI+) $m / z$ calcd for $\left[\mathrm{C}_{23} \mathrm{H}_{37} \mathrm{O}_{6} \mathrm{~N}_{2} \mathrm{~B}+\mathrm{H}\right]^{+} 449.2817$, found 449.2814 .

tert-Butyl

((2S,3S,6R,8aS)-2-methyl-4-0xo-6-((3aS,4S,6S,7aR)-3a,5,5trimethylhexahydro-4,6-methanobenzo $[d][1,3,2]$ dioxaborol-2-yl)hexahydro-2 $H$ -

pyrrolo[2,1-b][1,3]oxazin-3-yl)carbamate (13a). The product was synthesized according to general acid-catalyzed oxidative cyclization procedure B from peptide 22c and purified by flash 
chromatography on a silica gel column (eluent 60:40 hexanes-EtOAc) to give the product as a white foam (60\%). $R_{f}=0.43$ (70:30 hexanes-EtOAc); IR (film) $\mathrm{cm}^{-1} 3329,2929,1717,1671,1449$, 1389, 1376, 1368, 1165, 1054, 1031; ${ }^{1} \mathrm{H}$ NMR (500 MHz, Acetone- $\left.d_{6}\right) \delta 5.89$ (d, $\left.J=8.6 \mathrm{~Hz}, 1 \mathrm{H}\right)$, $5.40(\mathrm{dd}, J=6.3,2.3 \mathrm{~Hz}, 1 \mathrm{H}), 4.29(\mathrm{dd}, J=8.8,2.1 \mathrm{~Hz}, 1 \mathrm{H}), 4.19(\mathrm{t}, J=9.0 \mathrm{~Hz}, 1 \mathrm{H}), 3.74-3.56$ (m, 1H), 2.99 (t, $J=8.1 \mathrm{~Hz}, 1 \mathrm{H}), 2.34$ (ddt, $J=14.2,8.8,2.5 \mathrm{~Hz}, 1 \mathrm{H}), 2.25-2.12(\mathrm{~m}, 2 \mathrm{H}), 2.01$ - $1.96(\mathrm{~m}, 2 \mathrm{H}), 1.96-1.90(\mathrm{~m}, 2 \mathrm{H}), 1.90-1.85(\mathrm{~m}, 1 \mathrm{H}), 1.78(\mathrm{ddd}, J=14.5,3.4,2.1 \mathrm{~Hz}, 1 \mathrm{H})$, $1.43(\mathrm{~s}, 9 \mathrm{H}), 1.41(\mathrm{~s}, 3 \mathrm{H}), 1.32(\mathrm{~d}, J=6.2 \mathrm{~Hz}, 3 \mathrm{H}), 1.28(\mathrm{~d}, J=3.0 \mathrm{~Hz}, 4 \mathrm{H}), 0.87(\mathrm{~s}, 3 \mathrm{H}) ;{ }^{13} \mathrm{C} \mathrm{NMR}$ $\left(126 \mathrm{MHz}\right.$, Acetone- $\left.d_{6}\right) \delta 167.88,156.81,86.47,84.11,79.51,78.29,73.80,55.75,52.25,44.12$, $40.40,38.84,36.15,34.36,28.67,28.49$ (3C), 27.44, 26.86, 26.35, 24.25, 19.50; ${ }^{11} \mathrm{~B}$ NMR (161 $\mathrm{MHz}$, Acetone- $\left.d_{6}\right) \delta 31.74$; HRMS (ESI+) $m / z$ calcd for $\left[\mathrm{C}_{23} \mathrm{H}_{37} \mathrm{O}_{6} \mathrm{~N}_{2} \mathrm{~B}+\mathrm{H}\right]^{+} 449.2817$, found 449.2811.

\section{N-((3S,6R,8aS)-4-0xo-6-((3aS,4S,6S,7aR)-3a,5,5-Trimethylhexahydro-4,6-} methanobenzo[d][1,3,2]dioxaborol-2-yl)hexahydro-2H-pyrrolo[2,1-b][1,3] oxazin-3-

yl)acetamide (10d). Bicycle 10c (175 mg) was dissolved in EtOAc (15 mL), and AcOH was added ( $\sim 5$ drops). The solution was purged with Ar (bubbled into the solution) for 15 minutes. The $\mathrm{Pd} / \mathrm{C}$ catalyst was then added, and the mixture was purged with Ar (bubbled into the solution) for 5 minutes. The Ar balloon was replaced with an $\mathrm{H}_{2}$ balloon, and the mixture stirred overnight. The solid was then filtered through Celite ${ }^{\circledR}$ and rinsed with EtOAc. The filtrate was concentrated in vacuo to give a yellow oil, which was dissolved in DCM $(10 \mathrm{~mL})$, and the solution was cooled to $0^{\circ} \mathrm{C}$. Et $3 \mathrm{~N}$ (113 mg, $0.16 \mathrm{~mL}, 3 \mathrm{eq}$ ) was added, followed by acetyl chloride (35 mg, $0.031 \mathrm{~mL}, 1.2$ eq) and DMAP (5 mg, $0.1 \mathrm{eq}$ ). The solution was warmed to room temperature and stirred for $2 \mathrm{~h}$. Water was added, and the product was extracted with DCM. The combined organic layers were washed with brine, dried over $\mathrm{Na}_{2} \mathrm{SO}_{4}$, and concentrated in vacuo. The crude product was purified by flash chromatography on a silica gel column (eluent $100 \%$ EtOAc) to give the product as a white solid ( $89 \mathrm{mg}, 63 \%$ over 2 steps). $R_{f}=0.17$ (eluent $100 \%$ EtOAc); ${ }^{1} \mathrm{H} \mathrm{NMR} \mathrm{(500} \mathrm{MHz,}$ Acetone- $\left.d_{6}\right) \delta 7.16(\mathrm{~s}, 1 \mathrm{H}), 5.18(\mathrm{dd}, J=6.0,4.0 \mathrm{~Hz}, 1 \mathrm{H}), 4.60(\mathrm{dtd}, J=7.3,6.4,0.9 \mathrm{~Hz}, 1 \mathrm{H}), 4.29$ $(\mathrm{dd}, J=8.8,2.2 \mathrm{~Hz}, 1 \mathrm{H}), 4.22(\mathrm{dd}, J=10.4,7.5 \mathrm{~Hz}, 1 \mathrm{H}), 3.57(\mathrm{dd}, J=10.4,6.4 \mathrm{~Hz}, 1 \mathrm{H}), 3.04(\mathrm{t}$, $J=7.2 \mathrm{~Hz}, 1 \mathrm{H}), 2.35(\mathrm{ddt}, J=14.2,8.8,2.5 \mathrm{~Hz}, 1 \mathrm{H}), 2.27-2.19(\mathrm{~m}, 1 \mathrm{H}), 2.16(\mathrm{dtd}, J=10.7,6.1$, $2.2 \mathrm{~Hz}, 1 \mathrm{H}), 2.01-1.96(\mathrm{~m}, 2 \mathrm{H}), 1.96-1.92(\mathrm{~m}, 4 \mathrm{H}), 1.92-1.85(\mathrm{~m}, 2 \mathrm{H}), 1.78$ (ddd, $J=14.4$, 3.3, $2.2 \mathrm{~Hz}, 1 \mathrm{H}), 1.40(\mathrm{~s}, 3 \mathrm{H}), 1.35-1.29(\mathrm{~m}, 1 \mathrm{H}), 1.28(\mathrm{~s}, 3 \mathrm{H}), 0.87(\mathrm{~s}, 3 \mathrm{H}) ;{ }^{13} \mathrm{C} \mathrm{NMR}(126 \mathrm{MHz}$, Acetone- $\left.d_{6}\right) \delta 170.20,166.57,88.20,86.43,78.34,68.98,52.24,48.43,43.39,40.39,38.86,36.21$, 
$33.74,28.76,27.43,26.84,25.07,24.25,22.65 ;{ }^{11}$ B peak reported for major rotamer; full spectrum provided as Supporting Information. ${ }^{11} \mathrm{~B}$ NMR $\left(161 \mathrm{MHz}\right.$, Acetone- $\left.d_{6}\right) \delta 31.51,22.62$; HRMS (ESI+) $m / z$ calcd for $\left[\mathrm{C}_{19} \mathrm{H}_{29} \mathrm{O}_{5} \mathrm{~N}_{2} \mathrm{~B}+\mathrm{H}\right]^{+} 377.2242$, found 377.2244.

General procedure for the deprotection of $N$-Boc protected boronic esters. The boronic ester $(1 \mathrm{eq})$ was dissolved in DCM $(0.1 \mathrm{M})$, and the solution was cooled to $-78^{\circ} \mathrm{C} . \mathrm{BCl}_{3}(1 \mathrm{M}$ in DCM, 3.5 eq) was added dropwise, and the solution was stirred at $-78^{\circ} \mathrm{C}$ for $1 \mathrm{~h}$. $\mathrm{MeOH}(12 \mathrm{eq})$ was added slowly at $-78^{\circ} \mathrm{C}$. The solution was concentrated in vacuo, and the residue was dissolved in DCM. The product was extracted with water, and the combined aqueous phases were washed with $\mathrm{Et}_{2} \mathrm{O}$ and concentrated in vacuo to give the product as a solid with no further purification necessary.

(3S,6R,8aS)-6-Borono-4-oxohexahydro-2H-pyrrolo[2,1-b][1,3]oxazin-3-aminium chloride (10f). The product was synthesized from bicycle 10e according to the general procedure for the deprotection of $N$-Boc protected boronic esters, giving a sticky white solid (34\%). $R_{f}=$ does not elute on silica-backed TLC plates; IR (film) $\mathrm{cm}^{-1} 3206,3194,2845,1647,1477,1022$; ${ }^{1} \mathrm{H}$ NMR $\left(500 \mathrm{MHz}, \mathrm{DMSO}-d_{6}\right) \delta 8.68(\mathrm{~s}, 3 \mathrm{H}), 5.02(\mathrm{dd}, J=6.9,5.5 \mathrm{~Hz}, 1 \mathrm{H}), 4.14(\mathrm{dd}, J=12.1,6.2 \mathrm{~Hz}$, 1H), 4.08 (dd, $J=12.1,3.5 \mathrm{~Hz}, 1 \mathrm{H}), 3.91-3.85(\mathrm{~m}, 1 \mathrm{H}), 2.98(\mathrm{dd}, J=9.4,4.1 \mathrm{~Hz}, 1 \mathrm{H}), 2.14$ (dtd, $J=10.7,5.6,3.3 \mathrm{~Hz}, 1 \mathrm{H}), 1.93-1.80(\mathrm{~m}, 2 \mathrm{H}), 1.79-1.73(\mathrm{~m}, 1 \mathrm{H}) ;{ }^{13} \mathrm{C}$ NMR $(126 \mathrm{MHz}$, DMSO) $\delta 22.65,31.19,45.20,46.71,66.09,88.62,161.45 ;{ }^{11}$ B NMR (161 MHz, DMSO) $\delta$ 20.23; HRMS (ESI+) $m / z$ calcd for $\left[\mathrm{C}_{7} \mathrm{H}_{13} \mathrm{O}_{4} \mathrm{~N}_{2} \mathrm{~B}+\mathrm{H}\right]^{+}$201.1041, found 201.1039.

\section{$(3 R, 6 R, 8 \mathrm{a} R)$-6-Borono-4-oxohexahydro-2H-pyrrolo[2,1-b][1,3]oxazin-3-aminium}

chloride (11b). The product was synthesized from bicycle 11a according to the general procedure for the deprotection of $N$-Boc protected boronic esters, giving a sticky white solid (39\%). $R_{f}=$ does not elute on silica-backed TLC plates; IR (film) $\mathrm{cm}^{-1} 3206,2980,1653,1447,1191,1056 ;{ }^{1} \mathrm{H}$ NMR (500 MHz, DMSO- $\left.d_{6}\right) \delta 8.60$ (s, 3H), 5.05 (dd, $\left.J=7.9,5.4 \mathrm{~Hz}, 1 \mathrm{H}\right), 4.19$ (dd, $J=12.1,7.1$ Hz, 1H), 4.05 (dd, $J=12.1,3.4 \mathrm{~Hz}, 1 \mathrm{H}), 3.97-3.86$ (m, 1H), 3.21 (dd, $J=10.9,7.5 \mathrm{~Hz}, 1 \mathrm{H}), 2.21$ $(\mathrm{dtd}, J=11.3,5.8,1.6 \mathrm{~Hz}, 1 \mathrm{H}), 2.00(\mathrm{dtd}, J=12.3,7.1,1.5 \mathrm{~Hz}, 1 \mathrm{H}), 1.66(\mathrm{tt}, J=11.5,7.3 \mathrm{~Hz}$, $1 \mathrm{H}), 1.56(\mathrm{qd}, J=11.8,5.9 \mathrm{~Hz}, 1 \mathrm{H}) ;{ }^{13} \mathrm{C}$ NMR (126 MHz, DMSO) $\delta 23.05,32.39,46.12,46.81$, 66.38, 89.33, 161.95; ${ }^{11} \mathrm{~B}$ NMR (161 MHz, DMSO) $\delta$ 20.15; HRMS (ESI+) $\mathrm{m} / z$ calcd for $\left[\mathrm{C}_{7} \mathrm{H}_{13} \mathrm{O}_{4} \mathrm{~N}_{2} \mathrm{~B}+\mathrm{H}\right]^{+}$201.1041, found 201.1041. 
$(2 R, 3 S, 6 R, 8 \mathrm{a} S)$-6-Borono-2-methyl-4-oxohexahydro-2H-pyrrolo[2,1-b][1,3]oxazin-3-

aminium chloride (12c). The product was synthesized from bicycle $\mathbf{1 2 b}$ according to the general procedure for the deprotection of $N$-Boc protected boronic esters, giving a sticky white solid (41\%). $R_{f}=$ does not elute on silica-backed TLC plates; IR (film) $\mathrm{cm}^{-1} 3194,2892,1651,1445$, 1193, 1046; ${ }^{1} \mathrm{H}$ NMR (500 MHz, DMSO- $\left.d_{6}\right) \delta 8.54$ (d, $\left.J=5.4 \mathrm{~Hz}, 3 \mathrm{H}\right), 5.12(\mathrm{t}, J=5.9 \mathrm{~Hz}, 1 \mathrm{H})$, 4.34 (p, $J=6.4 \mathrm{~Hz}, 1 \mathrm{H}), 3.98$ (p, $J=5.6 \mathrm{~Hz}, 1 \mathrm{H}), 2.97$ (dd, $J=9.1,4.5 \mathrm{~Hz}, 1 \mathrm{H}), 2.18-2.03$ (m, $1 \mathrm{H}), 1.93-1.73(\mathrm{~m}, 3 \mathrm{H}), 1.21(\mathrm{~d}, J=6.5 \mathrm{~Hz}, 3 \mathrm{H}) ;{ }^{13} \mathrm{C}$ NMR (126 MHz, DMSO) $\delta 16.54,23.13$, $31.42,45.49,50.31,70.67,87.24,161.95 ;{ }^{11} \mathrm{~B}$ NMR (161 MHz, DMSO) $\delta 19.64$; HRMS (ESI+) $\mathrm{m} / z$ calcd for $\left[\mathrm{C}_{8} \mathrm{H}_{15} \mathrm{O}_{4} \mathrm{~N}_{2} \mathrm{~B}+\mathrm{H}\right]^{+} 215.1198$, found 215.1192

\section{(2S,3S,6R,8aS)-6-Borono-2-methyl-4-oxohexahydro-2H-pyrrolo[2,1-b][1,3]oxazin-3-}

aminium chloride (13b). The product was synthesized from bicycle 13a according to the general procedure for the deprotection of $N$-Boc protected boronic esters, giving a sticky white solid (52\%). $R_{f}=$ does not elute on silica-backed TLC plates; IR (film) $\mathrm{cm}^{-1} 3198,2948,1653,1477$, 1193, 1138; ${ }^{1} \mathrm{H}$ NMR (500 MHz, DMSO- $\left.d_{6}\right) \delta 8.63(\mathrm{~d}, J=4.7 \mathrm{~Hz}, 3 \mathrm{H}), 5.40-5.19(\mathrm{~m}, 1 \mathrm{H}), 4.28$ $-3.79(\mathrm{~m}, 2 \mathrm{H}), 3.21-2.87$ (m, 1H), $2.24-1.98(\mathrm{~m}, 1 \mathrm{H}), 1.98$ (s, 3H), 1.39 (d, $J=6.3 \mathrm{~Hz}, 3 \mathrm{H})$; ${ }^{13} \mathrm{C}$ NMR (126 MHz, DMSO) $\delta 18.85,24.70,31.99,46.74,52.40,70.24,83.35,162.86 ;{ }^{11} \mathrm{~B}$ NMR (161 MHz, DMSO) $\delta 20.09$; HRMS (ESI+) $\left[\mathrm{C}_{8} \mathrm{H}_{15} \mathrm{O}_{4} \mathrm{~N}_{2} \mathrm{~B}+\mathrm{H}\right]^{+} 215.1198$, found 215.1190

\section{Supporting Information.}

NMR spectra, dose-response curves for each compound (PDF)

\section{ORCID:}

Jessica Plescia: 0000-0002-8032-2047

Damien Hedou: 0000-0002-6511-8689

Anne Labarre: 0000-0003-4939-3928

Anthony Mittermaier: 0000-0002-3767-1225

Nicolas Moitessier: 0000-0001-6933-2079

\section{Acknowledgements}

We thank CIHR for support through an Operating Grant to NM and AKM (MOP 136943). JP was supported by a McGill University Molson and Hilton Hart Fellowship in Science, CD was supported by an NSERC scholarship. 
Abbreviations: POP, prolyl oligopeptidase; FAP, fibroblast activation protein- $\alpha$; DPP, dipeptidyl peptidase; TLC, thin layer chromatography

\section{References}

(1) Lawandi, J.; Gerber-Lemaire, S.; Juillerat-Jeanneret, L.; Moitessier, N. J Med Chem 2010, 53, 3423.

(2) Lambeir, A. M. Exp Opin Therap Pat 2011, 21, 977.

(3) López, A.; Tarragó, T.; Giralt, E. Exp Opin Therap Pat 2011, 21, 1023.

(4) Van Der Veken, P.; Fülöp, V.; Rea, D.; Gerard, M.; Van Elzen, R.; Joossens, J.; Cheng, J. D.; Baekelandt, V.; De Meester, I.; Lambeir, A. M.; Augustyns, K. J Med Chem 2012, 55, 9856.

(5) Brandt, I.; Gérard, M.; Sergeant, K.; Devreese, B.; Baekelandt, V.; Augustyns, K.; Scharpé, S.; Engelborghs, Y.; Lambeir, A.-M. Peptides 2008, 29, 1472.

(6) Hannula, M. J.; Myöhänen, T. T.; Tenorio-Laranga, J.; Männistö, P. T.; Garcia-Horsman, J. A. Neuroscience 2013, 242, 140.

(7) Savolainen, M. H.; Yan, X.; Myöhänen, T. T.; Huttunen, H. J. J Biol Chem 2015, 290, 5117.

(8) Svarcbahs, R.; Julku, U. H.; Norrbacka, S.; Myöhänen, T. T. Sci Rep 2018, 8, 1552.

(9) Savolainen, M. H.; Richie, C. T.; Harvey, B. K.; Männistö, P. T.; Maguire-Zeiss, K. A.; Myöhänen, T. T. Neurobiol Dis 2014, 68, 1.

(10) Myöhänen, T. T.; Norrbacka, S.; Savolainen, M. H. Neurosci Lett 2017, 636, 83.

(11) Svarcbahs, R.; Julku, U. H.; Myöhänen, T. T. J. Neurosci. 2016, 36, 12485.

(12) Kumar, R.; Bavi, R.; Jo, M. G.; Arulalapperumal, V.; Baek, A.; Rampogu, S.; Kim, M. O.; Lee, K. W. Sci Rep 2017, 7, 10827.

(13) Lambeir, A. M. CNS Neurol. Disort. Dr. 2011, 10, 349.

(14) Savolainen, M. H.; Yan, X.; Myöhänen, T. T.; Huttunen, H. J. J. Biol. Chem. 2015, 290, 5117.

(15) López, A.; Herranz-Trillo, F.; Kotev, M.; Gairí, M.; Guallar, V.; Bernadó, P.; Millet, O.; Tarragó, T.; Giralt, E. ChemBioChem 2016, 17, 913.

(16) Liu, J. M.; Kusinski, M.; Ilic, V.; Bignon, J.; Hajem, N.; Komorowski, J.; Kuzdak, K.; Stepien, H.; Wdzieczak-Bakala, J. Anticancer Res 2008, 28, 2813.

(17) Suzuki, K.; Sakaguchi, M.; Tanaka, S.; Yoshimoto, T.; Takaoka, M. Biochem Biophys Res Commun 2014, 443, 91.

(18) Tanaka, S.; Suzuki, K.; Sakaguchi, M. Breast Cancer 2017, 1.

(19) Lawandi, J.; Toumieux, S.; Seyer, V.; Campbell, P.; Thielges, S.; Juillerat-Jeanneret, L.; Moitessier, N. J Med Chem 2009, 52, 6672.

(20) De Cesco, S.; Deslandes, S.; Therrien, E.; Levan, D.; Cueto, M.; Schmidt, R.; Cantin, L. D.; Mittermaier, A.; Juillerat-Jeanneret, L.; Moitessier, N. J Med Chem 2012, 55, 6306.

(21) Kelly, T.; Huang, Y.; Simms, A. E.; Mazur, A. Int Rev Cell Mol Biol 2012, 297, 83.

(22) Santos, A. M.; Jung, J.; Aziz, N.; Kissil, J. L.; Puré, E. J Clin Invest 2009, 119, 3613.

(23) Franco, O. E.; Hayward, S. W. Adv Pharmacol 2012, 65, 267.

(24) Liu, R.; Li, H.; Liu, L.; Yu, J.; Ren, X. Cancer Biol Ther 2012, 13, 123.

(25) Park, J. E.; Lenter, M. C.; Zimmermann, R. N.; Garin-Chesa, P.; Old, L. J.; Rettig, W. J. J Biol Chem 1999, 274, 36505. 
(26) Cheng, J. D.; Dunbrack Jr, R. L.; Valianou, M.; Rogatko, A.; Alpaugh, R. K.; Weiner, L. M. Cancer Res 2002, 62, 4767.

(27) Rettig, W. J.; Garin-Chesa, P.; Healey, J. H.; Su, S. L.; Ozer, H. L.; Schwab, M.; Albino, A. P.; Old, L. J. Cancer Res 1993, 53, 3327.

(28) Ryabtsova, O.; Jansen, K.; Van Goethem, S.; Joossens, J.; Cheng, J. D.; Lambeir, A. M.; De Meester, I.; Augustyns, K.; Van Der Veken, P. Bioorg Med Chem Lett 2012, 22, 3412.

(29) Jansen, K.; Heirbaut, L.; Cheng, J. D.; Joossens, J.; Ryabtsova, O.; Cos, P.; Maes, L.; Lambeir, A. M.; De Meester, I.; Augustyns, K.; Van Der Veken, P. ACS Med Chem Lett 2013, 4, 491.

(30) Poplawski, S. E.; Lai, J. H.; Li, Y.; Jin, Z.; Liu, Y.; Wu, W.; Wu, Y.; Zhou, Y.; Sudmeier, J. L.; Sanford, D. G.; Bachovchin, W. W. J Med Chem 2013, 56, 3467.

(31) Bainbridge, T. W.; Dunshee, D. R.; Kljavin, N. M.; Skelton, N. J.; Sonoda, J.; Ernst, J. A. Sci Rep 2017.

(32) Christiansen, V. J.; Jackson, K. W.; Lee, K. N.; Downs, T. D.; McKee, P. A. Neoplasia 2013, 15.

(33) Jackson, K. W.; Christiansen, V. J.; Yadav, V. R.; Silasi-Mansat, R.; Lupu, F.; Awasthi, V.; Zhang, R. R.; McKee, P. A. Neoplasia 2015, 17, 43.

(34) Tsai, T.-Y.; Yeh, T.-K.; Chen, X.; Hsu, T.; Jao, Y.-C.; Huang, C.-H.; Song, J.-S.; Huang, Y.-C.; Chien, C.-H.; Chiu, J.-H.; Yen, S.-C.; Tang, H.-K.; Chao, Y.-S.; Jiaang, W.-T. J Med Chem 2010, 53, 6572.

(35) Tran, T.; Quan, C.; Edosada, C. Y.; Mayeda, M.; Wiesmann, C.; Sutherlin, D.; Wolf, B. B. Bioorg Med Chem Lett 2007, 17, 1438.

(36) Kaszuba, K.; Róg, T.; Danne, R.; Canning, P.; Fülöp, V.; Juhász, T.; Szeltner, Z.; St. Pierre, J. F.; García-Horsman, A.; Männistö, P. T.; Karttunen, M.; Hokkanen, J.; Bunker, A. Biochimie 2012, 94, 1398.

(37) Schiavini, P.; Pottel, J.; Moitessier, N.; Auclair, K. ChemMedChem 2015, 10, 1174.

(38) Mariaule, G.; De Cesco, S.; Airaghi, F.; Kurian, J.; Schiavini, P.; Rocheleau, S.; Huskić, I.; Auclair, K.; Mittermaier, A.; Moitessier, N. J Med Chem 2016, 59, 4221.

(39) Corbeil, C. R.; Englebienne, P.; Moitessier, N. J Chem Inf Model 2007, 47, 435.

(40) Moitessier, N.; Corbeil, C. R. J Chem Inf Model 2009, 49, 997.

(41) Moitessier, N.; Pottel, J.; Therrien, E.; Englebienne, P.; Liu, Z.; Tomberg, A.; Corbeil, C. R. Acc Chem Res 2016, 49, 1646.

(42) Cunningham, C. C. Exp Opin Investig Drugs 2007, 16, 1459.

(43) Plescia, J.; De Cesco, S.; Patrascu, M. B.; Kurian, J.; Di Trani, J.; Dufresne, C.; Wahba, A. S.; Janmamode, N.; Mittermaier, A. K.; Moitessier, N. J Med Chem 2019, 62, 7874.

(44) Plescia, J.; Dufresne, C.; Janmamode, N.; Wahba, A. S.; Mittermaier, A. K.; Moitessier, N. Eur J Med Chem 2020, 185, 111783.

(45) Smoum, R.; Rubinstein, A.; Dembitsky, V. M.; Srebnik, M. Chem Rev 2012, 112, 4156.

(46) Trippier, P. C.; McGuigan, C. MedChemComm 2010, 1, 183.

(47) Gentile, M.; Offidani, M.; Vigna, E.; Corvatta, L.; Recchia, A. G.; Morabito, L.; Morabito, F.; Gentili, S. Exp Opin Investig Drugs 2015, 24, 1287.

(48) Michaelis, A.; Becker, P. Berichte der deutschen chemischen Gesellschaft 1880, 13, 58.

(49) Michaelis, A.; Becker, P. Berichte der deutschen chemischen Gesellschaft 1882, 15, 180.

(50) Lai, J. H.; Wu, W.; Zhou, Y.; Maw, H. H.; Liu, Y.; Milo Jr, L. J.; Poplawski, S. E.; Henry, G. D.; Sudmeier, J. L.; Sanford, D. G.; Bachovchin, W. W. J Med Chem 2007, 50, 2391.

(51) Liu, G.; Cogan, D. A.; Owens, T. D.; Tang, T. P.; Ellman, J. A. J Org Chem 1999, 64, 1278. 
(52) Mabic, S.; Cordi, A. A. Tetrahedron 2001, 57, 8861.

(53) Beenen, M. A.; An, C.; Ellman, J. A. J Am Chem Soc 2008, 130, 6910.

(54) Li, C.; Wang, J.; Barton, L. M.; Yu, S.; Tian, M.; Peters, D. S.; Kumar, M.; Yu, A. W.; Johnson, K. A.; Chatterjee, A. K.; Yan, M.; Baran, P. S. Science 2017, 356.

(55) Rhodes, C. A.; Pei, D. Chemistry 2017, 23, 12690.

(56) Jansen, K.; Heirbaut, L.; Verkerk, R.; Cheng, J. D.; Joossens, J.; Cos, P.; Maes, L.; Lambeir, A. M.; De Meester, I.; Augustyns, K.; Van der Veken, P. J Med Chem 2014, 57, 3053.

(57) Abagyan, R.; Totrov, M. J Mol Biol 1994, 235, 983.

(58) Fustero, S.; Diego Jiménez; Sánchez-Roselló, M.; Pozo, C. d. J Am Chem Soc 2007, 129, 6700 .

(59) Babij, N. R.; Wolfe, J. P. Angew Chem Int Ed 2012, 51, 4128.

(60) Saito, Y.; Ouchi, H.; Takahata, H. Tetrahedron 2008, 64, 11129. 